OPEN ACCESS

Edited by:

Ehsan Elahi,

Shandong University of Technology,

China

Reviewed by: Xinru Han

Institute of Agricultural Economics and Development (CAAS), China Leqian Ouyang, Central South University, China

*Correspondence: Chengyin Huang hcy@cqu.edu.cn

Specialty section: This article was submitted to Environmental Economics and Management, a section of the journal Frontiers in Environmental Science

Received: 18 November 2021 Accepted: 13 December 2021 Published: 10 January 2022

Citation: Huang $C$ and Chen Y (2022) How to Enhance the Green Innovation of Sports Goods? Micro- and MacroLevel Evidence From China's Manufacturing Enterprises. Front. Environ. Sci. 9:809156. doi: 10.3389/fenvs.2021.809156

\section{How to Enhance the Green Innovation of Sports Goods? Micro- and Macro-Level Evidence From China's Manufacturing Enterprises}

\author{
Chengyin Huang * and Ying Chen \\ College of Physical Education, Chongqing University, Chongqing, China
}

This study aims to explore the driving factors of green innovation, and uses the micro- and macro-data from China's sports goods manufacturing industries. In particularly, sports goods manufacturing enterprises are identified by the textual analysis of information disclosure, and the competitive environment faced by each enterprise is built through their unique closest rivals. Empirically, this study finds that competition and policy can promote green innovation in sports goods manufacturing industries, and industrial policy can moderate the role of product market competition in promoting green innovation. Considering the characteristics of the Chinese market, more industrial policies may intensify the competition among manufacturing enterprises, forcing such enterprises to obtain competitive advantages through innovation outcomes. It is worth noting that the association between product market competition and green innovation changes as financial constraints increase, and this may be caused by the impact of industrial policy on the interactions among enterprises. After implementing the strict environmental policy, product market competition and industrial policy can both promote green innovation. In high-polluting industries, sports goods manufacturing enterprises get more social attention and suffer from higher penalties for environmental violations, so that such enterprises will get more motivations from industrial policies to support green innovation. In addition, we also find that there is a significant inverted- $U$ shape relationship between industrial policy and green innovation in sports goods manufacturing industries. As financial constraints increase, the non-linear relationship between product market competition and green innovation converts from a $U$ shape relationship to an inverted-U shape relationship. Our findings can provide a better understanding of the investment of sports goods manufacturing enterprises in green innovation.

Keywords: sports goods manufacturing enterprise, textual analysis, market competition, industrial policy, green innovation 


\section{INTRODUCTION}

Green innovation, as an important approach to ameliorate environmental degradation, can help organizations to achieve the goal of reducing energy consumption and improving energy efficiency (Chu et al., 2019). This special kind of innovation can be defined as a process that contributes to the creation of new production and technologies with the aim of reducing the negative impact of enterprises on the ecological environment and gaining environmental benefits (Castellacci and Lie, 2017). Compared with other industries, manufacturing enterprises present the government with a dilemma: whether they need to reduce environmental pollution by restricting their operation, or promote economic development through increasing their production (Cheng and Liu, 2018). However, most developing countries often adopt the strategy of "treatment after pollution," and ignore environmental risks created by manufacturing enterprises (Xiang et al., 2021). It can be seen that manufacturing industries will be still regarded as the main factor damaging the ecological environment. Considering increasing social, environmental and political forces, manufacturing enterprises have to explore some new products or technologies for mitigating environmental risks, so as to achieve the goal of protecting the ecological environment (Castellacci and Lie, 2017).

Sports goods manufacturing enterprises, as a special kind of manufacturing enterprises, produce various sports-related products which have become part of everyday life. Due to low labor costs, some developing countries have long been world factories, and sports goods manufacturing industries play an important role in regional economic development, particularly in developing countries. In Figure 1, the export of sports goods in developing countries is significantly higher than that in developed countries, indicating that developing countries are more dependent on the output of sports goods manufacturing industries.

Unfortunately, the production of sports goods causes some environmental pollution problems, e.g., air pollution and water pollution. Based on that, the investment in green innovation of sports goods manufacturing enterprises will be directly reflected in competitive advantages and environmental benefits. In the global sports goods market, China, as the largest sports goods manufacturer in the world, can offer the widest variety of sportsrelated products. In 2016, there were 4 million sports goods manufacturing enterprises in China. In Figure 2, the growth rate of value-added by the manufacture of sports goods was higher than that of GDP from 2010 to 2018 in China, and there were rapid development trends in 2015 and 2018 respectively. Most sports goods manufacturing enterprises in the Chinese market are significantly smaller than other manufacturing enterprises, as well as their profitability. Faced with these two limitations, it is difficult for sports goods manufacturing enterprises to effectively maintain their investment in green innovation. However, there has been a rising tendency that sports goods manufacturing enterprises apply for green patents. Therefore, exploring the driving factors of green innovation can better explain why China's sports goods manufacturing enterprises strive for green innovation under internal limitations.

From the resource-based view, the investment in green innovation may be affected by organizational and macro factors (KarimiTakalo et al., 2021). Considering the characteristics of China's sports goods manufacturing enterprises, the limitation of organizational resources will be a challenging problem for supporting the investment in green innovation, and the driving factors of green innovation may come from the external environment. On the one hand, based on the innovation theory of Schumpeter, the competition among enterprises will affect the innovation preference of managers,

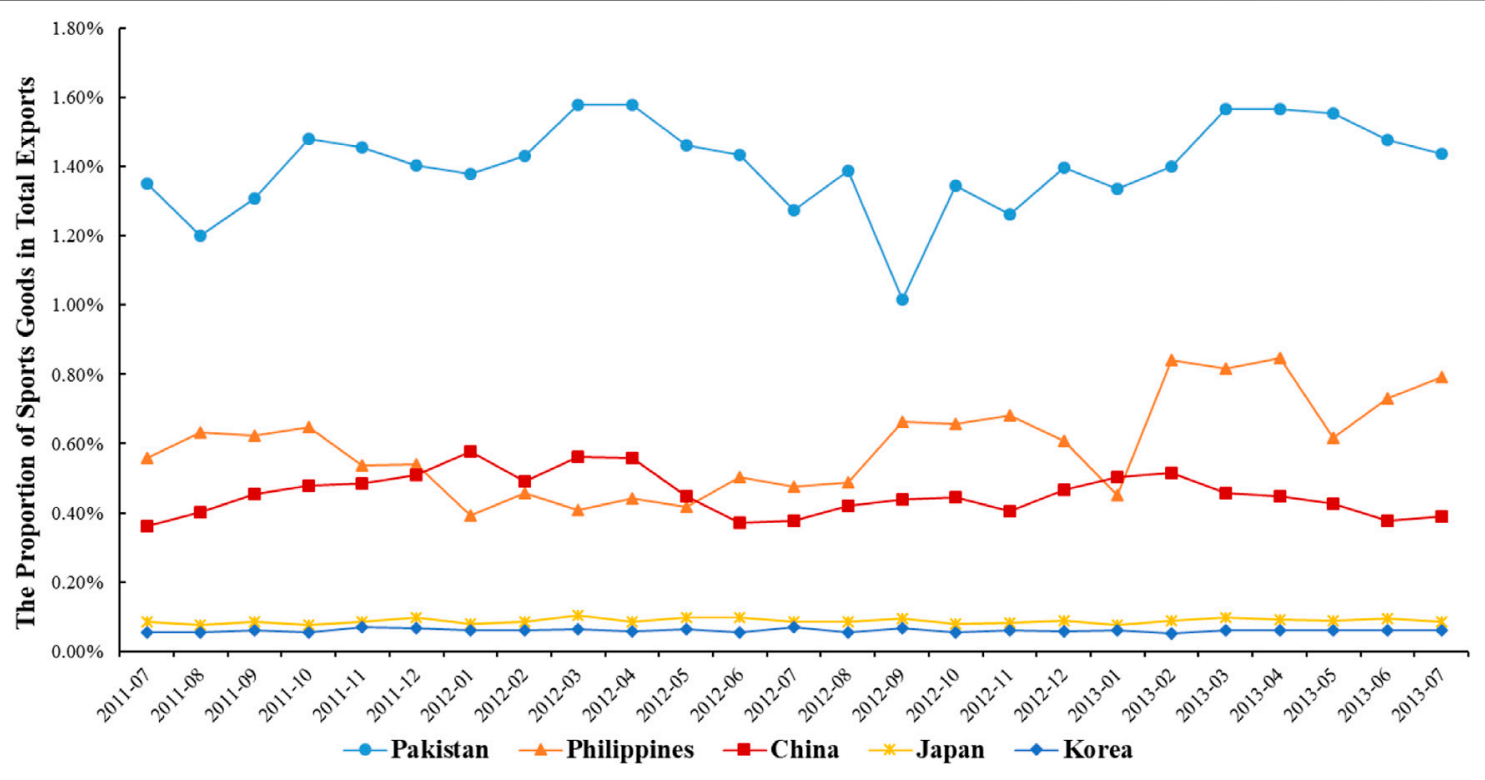

FIGURE 1 | The Exports of Sports Goods in Asian countries. 


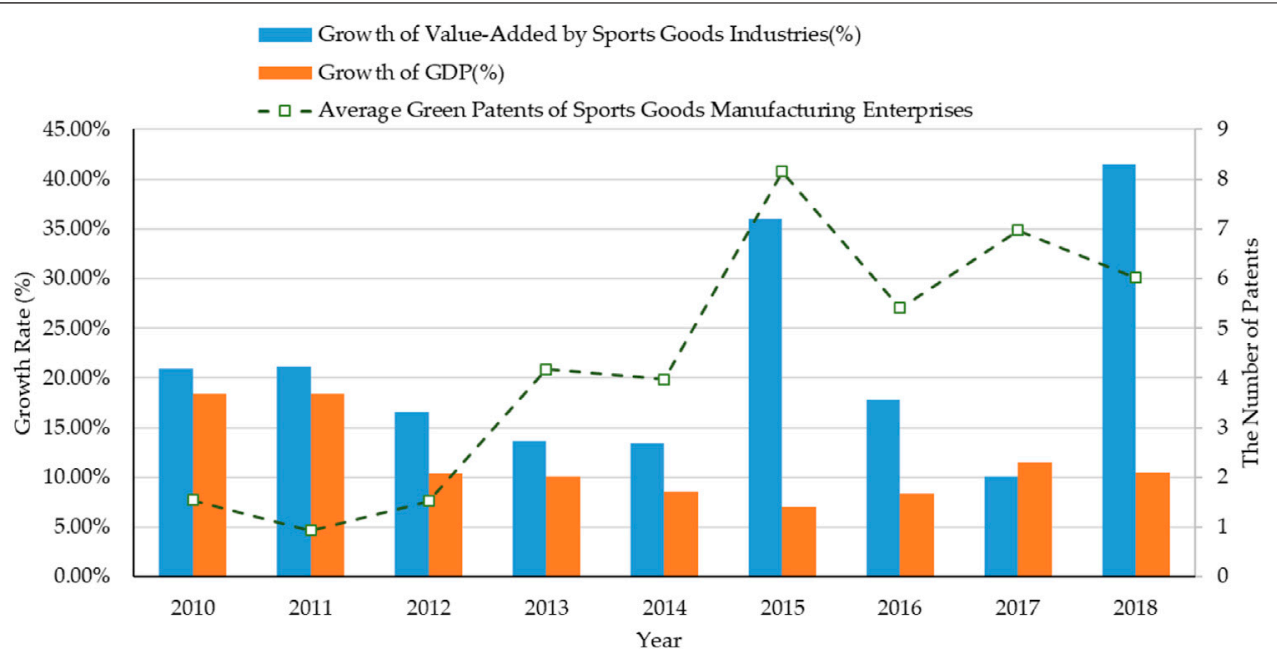

FIGURE 2 | Sports goods industries in China.

indicating that external pressure can change the resource allocation of organizations in research and development (R\&D) activities (Schumpeter and Backhaus, 2021). Although the investment in green innovation can help enterprises obtain competitive advantages, it is difficult for enterprises to obtain economic benefits in a short time. On the other hand, there is a close relationship between sports goods and sporting events, and thus the development strategy of sports goods manufacturing enterprises may be affected by international sporting events (Chen et al., 2020). In 2008, the Beijing Olympic Games promoted the demand for sports goods and accelerated the development of sports-related industries. The influence of sporting events on sports goods manufacturing enterprises comes from macro policies, and sports-related industrial policies may promote the R\&D activities of such enterprises. China's sports goods manufacturing enterprises depend heavily on subsidies from sports-related industrial policies, which provide enough financial support for their green innovation. According to these two external factors, we will explore whether the green innovation of sports goods manufacturing enterprises can be affected by product market competition or industrial policies.

During the analysis of the driving factors of green innovation, panel data models are constructed by utilizing a sample of Chinalisted companies in sports goods manufacturing industries from 2010 to 2018. In order to describe sports goods market competition, this study expands the method of Hoberg and Phillips (2016) to build the unique competitive environment of sports goods manufacturing enterprises by using textual analysis (Hoberg and Phillips, 2016). The empirical results show that product market competition can promote the green innovation of sports goods manufacturing enterprises, as well as industrial policy. Moreover, industrial policy can enhance the promotion of product market competition on green innovation. These findings can be explained by the theory of industrial organization, that is managers will get more motivations from industrial policies to improve their products or change their portfolio of products, which will also alter the product differentiation among enterprises. Considering the characteristics of the Chinese market, industrial policy may change the competition intensity among sports goods manufacturing enterprises, and such enterprises need to use green innovation outcomes to obtain competitive advantage. In terms of financial conditions, the association between product market competition and green innovation changes as financial constraints increase, and this may be due to the influence of industrial policy. Under the loose environmental policy, industrial policy can change the role of product market competition in promoting green innovation. After implementing the environmental policy, both product market competition and industrial policy can promote green innovation. Different from non-high-polluting enterprises, high-polluting enterprises can obtain more motivations from industrial policies to support green innovations, but the competitive environment faced by such enterprises cannot affect their green innovation. Furthermore, this study finds that there is a significant inverted-U shape relationship between industrial policy and green innovation in sports goods manufacturing industries. With the increase of financial constraints, the non-linear relationship between product market competition and green innovation will be changed from a $U$ shape relationship to an inverted-U shape relationship. The non-linear results demonstrate that industrial policy can play a moderating role in the association between product market competition and green innovation

This study makes several contributions: Firstly, based on the idea of Hoberg and Phillips (2016), this study constructs a Chinese vocabulary of sports goods for China's sports goods manufacturing enterprises, and measures the degree of product similarity to build the competitive environment faced by any of such enterprises (Hoberg and Phillips, 2016). Secondly, it is found that special conditions can change the relationship between product market competition and green innovation herein, especially the different levels of financial constraints and the 
implementation of environmental policy, which be consistent with Schumpeter's innovation theory (Schumpeter and Backhaus, 2021). Finally, from the resource-based view, our theoretical arguments and empirical findings highlight that sports-related industrial policies can change the role of product market competition in promoting the green innovation of sports goods manufacturing enterprises. This further discovery based on the resource-based theory has very important practical significance for policymakers, which is of great practical significance to policymakers.

The structure of this study is as follows: Section two focuses on the literature review and research hypotheses; Section three illustrates the measurement of sports goods market competition; Section four provides the empirical model; Section 5 presents the empirical results; Section 6 discusses the findings from empirical results; Section 7 puts forward the conclusions and recommendations.

\section{LITERATURE REVIEW AND RESEARCH HYPOTHESES}

\subsection{Green Innovation}

The core value of green innovation is creating potential environmental benefits and providing competitive advantages for enterprises (Chen, 2008). According to the resource-based view, the unique competitive advantages of enterprises mainly come from the investment in green products or the improvement of green technology, which can relieve the pressure of market share (Noci and Verganti, 1999; Chang, 2019). Although the environmental performance of green innovation is unpredictable, this kind of innovation outcome can meet the demands of governments and the public, to force managers to pay more attention to energy conservation and environmental protection. Therefore, many studies on green innovation were motivated by the driving factors of innovation outcomes (KarimiTakalo et al., 2021).

Corporate innovation needs to be supported by a large number of internal resources and is a serious challenge for the long-term development of companies (Thomas et al., 2021). As a form of organizational resource management, the investment in green technology can improve the competitive advantages of enterprises, as well as their green images (Chen, 2008). Under the pressure of stakeholders, managers need to invest more resources and funds in green innovation to maintain environmental benefits and reduce environmental risks (Lin et al., 2014). Although green innovation can be seen as the outcome of the allocation of internal resources, this process will be also affected by organizational and macro factors (Jun et al., 2019). In terms of organizational factors, green innovation may be limited by the internal resources of enterprises (Oduro et al., 2021). Amore and Bennedsen (2016) argued that corporate governance contributes to innovation performance, and inefficient management can hinder managers' motivation for green technologies (Amore and Bennedsen, 2016). However, there are also some characteristics of enterprises that can promote green innovation. Chang (2019) explored the relationship between green motivation and green innovation, and pointed out that moral factors are indispensable in improving the environmental performance of green innovation (Chang, 2019). Tariq et al. (2019) pointed out that established firms have a higher demand for green innovation (Tariq et al., 2019). Zhang et al. (2020) found that the demand for green innovation mainly stems from the environmental performance of innovation outcomes, which will enhance the competitive advantage of enterprises (Zhang et al., 2020). Zhao et al. (2018) believed that the pressure of stakeholders is an important factor in promoting green innovation. In terms of macro factors, government support is vital to the success of green innovation (Zhao et al., 2018). Huang et al. (2019) held the view that government subsidies can prove a decisive factor in green innovation (Huang et al., 2019). Jun et al. (2019) demonstrated that the auspices of a government initiative are the driving forces for small or medium-sized businesses (SMEs) to invest in green technology (Jun et al., 2019). Stucki et al. (2018) found that energy policies can influence green innovation in terms of the demand of green products, as an indication that green innovation outcomes can be affected by macroeconomic factors (Stucki et al., 2018). Zhang et al. (2021a) explored the relationship between stock market liberalization and green innovation, demonstrating that the development of the capital market can promote green innovation (Zhang et al., 2021a). Huang and Li (2017) found that social reciprocity can force managers to pay more attention to environmental performance generated by green innovation (Huang and Li, 2017). It is worth noting that some policies cannot change managers' motivation for investing in green innovation. Yi et al. (2019) discussed the impacts of different types of environmental policies on green innovation, and pointed out that China's environmental policy cannot effectively improve the investment of enterprises in green technology, indicating that the impact effect of policy factors may be limited by policy content (Yi et al., 2019).

According to the existing studies on green innovation, the environmental benefits of green innovation have been recognized by most researchers, and the exploration of driving factors of green innovation can create practical values for a technology upgrade, especially in manufacturing industries. In this situation, manufacturing enterprises' demands for green innovation are significantly higher than those of other industries (Chang, 2018; KarimiTakalo et al., 2021). Therefore, exploring the driving factors of green innovation in sports goods manufacturing industries can help such enterprises to reap increasing environmental benefits and economic profitability.

\subsection{Product Market Competition and Green Innovation}

In the innovation theory of Schumpeter, there is a close relationship between market competition and corporate innovation, and innovation outcomes can be an important way for enterprises to alleviate the pressure of market share (Bonfatti and Pisano, 2020). In the product market, the degree of competition will result in the different efforts of enterprises in green innovation. On the one hand, competition can promote 
corporate innovation for improving the degree of product differentiation, and innovation outcomes can also enhance the competitive advantages of enterprises. On the other hand, excessive competition may hinder corporate innovation, and then promote the similarity of products with reducing the profitability of enterprises. Therefore, there may be a nonlinear relationship between product market competition and green innovation (Aghion et al., 2005; Bonfatti and Pisano, 2020).

In terms of the promotion of product market competition, competition is an essential factor in promoting green products and green technology (Damanpour, 2010). Park et al. (2014) discussed the impacts of competition and cooperation on corporate innovation and found that a significant positive correlation between balanced cooperation and innovation outcomes (Park et al., 2014). Crowley and Jordan (2017) argued convincingly that market competition can promote corporate innovation in emerging markets, but the increase in the number of rivals will inhibit this positive association (Crowley and Jordan, 2017). Xia and Liu (2017) found that competition from state-owned enterprises can promote the technological innovation of private enterprises, indicating that resource interdependence plays an important role in corporate innovation (Xia and Liu, 2017). Marshall and Parra (2019) believed that the similarity of products can enhance the demand of enterprises for green innovation outcomes (Marshall and Parra, 2019). Market competition, Cao et al. (2020) suggested, can significantly promote the innovation outcomes of high-tech enterprises (Cao et al., 2020). Le et al. (2021) described the product market competition from the micro perspective, and found that the promotion effect of competition on corporate innovation is more significant in SMEs, indicating that SMEs need to use innovation outcomes to alleviate the pressure of product market competition (Le et al., 2021). In terms of the inhibition of product market competition, competition may reduce the demand of manufacturing enterprises for green innovation (Weiss and Wittkopp, 2005; Im et al., 2015). Ayyagari et al. (2011) pointed that the negative impact of product market competition on green innovation is mainly due to the increase in financial constraints (Ayyagari et al., 2011). Lyandres and Palazzo (2016) revealed that product market competition will enhance the dependence of enterprises on external finance and hinder green technology innovation (Lyandres and Palazzo, 2016). Wang and Mogi (2017) found that competition will cause managers to focus more on shortterm profits, and thus ignore the potential economic and environmental benefits of green innovation (Wang and Mogi, 2017). Mulkay (2019) discussed the relationship between market competition and corporate innovation and found that excessive competition will have a negative impact on innovation outcomes (Mulkay, 2019). To better explain this conflict, the nonlinear relationship between product market competition and corporate innovation has become a new research idea (Brodzicki, 2019). Aghion et al. (2015) demonstrated that there is an inverted-Ushaped relationship between product market competition and corporate innovation (Aghion et al., 2015). Peneder and Woerter (2014) found similar results and pointed out that different degrees of competition can change managers' preferences for innovation outcomes (Peneder and Woerter, 2014). Bonfatti and Pisano (2020) found that the innovation performance of enterprises will be affected by both market competition and financial constraints, and financial constraints can moderate the nonlinear relationship between market competition and enterprise innovation (Bonfatti and Pisano, 2020).

Technological innovation depends on the managers' reaction to market competition, which is an important factor in affecting green innovation (Tang, 2006). In China's manufacturing industries, sports goods manufacturing enterprises are significantly smaller than other manufacturing enterprises, as well as their profitability. The competition among such enterprises will make managers pay more attention to environmental benefits and long-term development strategies. Considering the characteristics of sports goods, enterprises need to use green products and green technology to alleviate the pressure of market share, and then obtain the recognition of stakeholders (Cao et al., 2020). We therefore hypothesize,

Hypothesis 1a (H1a). There is a positive association between product market competition and green innovation in sports goods manufacturing industries.

Hypothesis $1 \mathrm{~b}$ ( $\mathrm{H} 1 \mathrm{~b})$. There is a nonlinear relationship between product market competition and green innovation in sports goods manufacturing industries.

\subsection{Industrial Policy and Green Innovation}

Industrial policy has long been an important way to pursue industrial structure reform (Yi et al., 2019). During the implementation of industrial policy, enterprises need to use technological innovation to obtain a higher external evaluation, especially in environmental protection. Reflecting the government initiative in specific markets, the implementation of industrial policies will change the competition among enterprises, thus forcing them to promote technological innovation (Aghion et al., 2015).

The impacts of industrial policy on green innovation mainly come from two dimensions, namely direct impact and indirect impact. In terms of the direct impact of industrial policy, implementing industrial policy can directly enhance managers' attention to environmental performance, so as to enhance the investment of enterprises in green innovation (Bergek and Berggren, 2014). Liao (2018) pointed out that industrial policies related to environmental protection can effectively promote enterprises' sustainability, and such policies will play an important role in promoting their green innovation (Liao, 2018). Feng (2019) found that industrial policies can improve the innovation efficiency of enterprises, and promote enterprises to invest more resources in green innovation (Feng, 2019). Brunel (2019) pointed out that industrial policy can motivate enterprises to adopt foreign green technologies (Brunel, 2019). Yuan and Zhang (2020) believed that industrial policy can promote green innovation, and this positive effect will also enhance enterprises' sustainability (Yuan and Zhang, 2020). Lv et al. (2020) found that strict industrial policies can force enterprises to invest more resources in green innovation ( $\mathrm{LV}$ et al., 2020). In terms of the indirect impact of industrial policy, Griffith et al. (2010) showed 
that industrial policy can pursue product market reform, and then promote the technological innovation of manufacturing enterprises (Griffith et al., 2010). As Newell (2010) argued, industrial policies can change the preference of enterprises in energy consumption, so as to enhance the investment of enterprises in technological innovation (Newell, 2010). Aghion et al. (2015) expressed the view that enterprises need to alleviate the impact of competition on profitability through innovation outcomes, and industrial policy can promote this motivation (Aghion et al., 2015). Murphy et al. (2016) found that industrial policy can change the social capital of enterprises, as well as managers' preference in green innovation (Murphy et al., 2016). Bhattacharya et al. (2017) discussed the impact of industrial policy and policy uncertainty on corporate innovation, and inferred that industrial policy related to industrial structure reform can significantly promote technological innovation (Bhattacharya et al., 2017). Wang and Zou (2018) analyzed the relationship between different types of policies and technological innovation, and found that industrial policies related to environmental protection will promote the green innovation of state-owned enterprises (Wang and Zou, 2018). Uyarra e $t$ al. (2020) suggested that industrial policy can improve enterprises' investment in technological innovation due to government subsidies (Uyarra et al., 2020).

The Industrial policy reflects the degree of government support for specific industries, which further demonstrates the important role of government in industrial structure reform. For sports goods manufacturing enterprises, government support can motivate such enterprises to invest more resources in technological innovation and product innovation, to create opportunities for environmentally friendly practices [47]. Therefore, this study proposes the following hypotheses:

Hypothesis 2a ( $\mathrm{H} 2 \mathrm{a})$. There is a positive association between industrial policy and green innovation in sports goods manufacturing industries.

Hypothesis 2b (H2b). There is a nonlinear relationship between industrial policy and green innovation in sports goods manufacturing industries.

\subsection{Product Market Competition, Industrial Policy and Green Innovation}

From the macroeconomic environment, product market competition can be affected by industrial policy, especially in developing countries. In this situation, the innovation behavior of enterprises may be affected by both competition and policy. It is worth noting that the implementation of industrial policy will directly strengthen the degree of competition among manufacturing enterprises, and then force such enterprises to use green innovation to alleviate the pressure of market share (Griffith et al., 2010). In the theory of industrial organization, managers' reaction to market competition is to alleviate the pressure of market share. Competitive advantages can be provided by green innovation outcomes to help such enterprises to gain economic profitability and environmental benefits (Aghion et al., 2015; Zhang et al., 2021b). In addition, industrial structure reform will change the position of enterprises

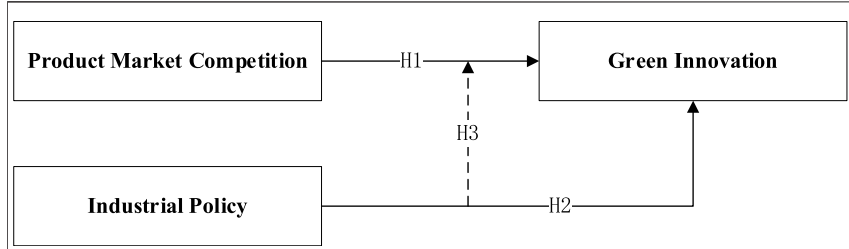

FIGURE 3 | Conceptual framework.

in their product markets, which may aggravate the degree of competition among enterprises (Cao et al., 2020). Based on the existing studies on product market competition, researchers mostly describe the competition among enterprises from the dimension of industry classification, but it is difficult to show the real competitive environment faced by enterprises (Hoberg and Phillips, 2016). For sports goods manufacturing enterprises, green innovation can help such enterprises to obtain unique competitive advantages and then alleviate the pressure from the changes of market structure. In this situation, an industrial policy may change the role of competition in promoting the green innovation of sports goods manufacturing enterprises. Therefore, this study proposes the following hypothesis:

Hypothesis 3 (H3). Industrial policy can moderate the association between product market competition and green innovation in sports goods manufacturing industries.

The conceptual framework of this paper is shown in Figure 3.

\section{MEASUREMENT OF SPORTS GOODS MARKET COMPETITION}

The traditional method of product market competition is mainly based on the concentration of a specific industry, and enterprises in the same industry will face the same competitive environment (Katselas et al., 2019). This method, however, has some obvious limitations. Firstly, there is no clear definition for China's sports goods manufacturing industry, and it is impossible to define industry boundaries among such enterprises. Faced with this problem, the degree of product market competition in sports goods manufacturing industries cannot be accurately measured. Secondly, sports goods manufacturing enterprises usually provide many kinds of sports-related products. Product diversification makes it difficult to describe the competition between firm A and firm B through a single product. Finally, the degree of product market competition at the macro level is difficult to show the real competitive environment faced by sports goods manufacturing enterprises.

Based on the above limitations, this study expands the method of Hoberg and Phillips (2016) through the sports goods vocabulary used in the annual reports of sports goods manufacturing enterprises and measures the degree of competition in sports goods market for such enterprises (Hoberg and Phillips, 2016). This study collects some words about sports goods, then identifies China's sports goods manufacturing enterprises through our sports goods vocabulary, and finally computes the degree of sports goods market competition for every selected enterprise. 


\subsection{Construction of Sports Goods Vocabulary}

According to the International Standard Industrial Classification (ISIC) published by United Nations, the manufacture of sports goods includes the manufacture of articles and equipment for sports, outdoor and indoor games, namely balls, rackets, bats, clubs, skis, bindings, poles, ski-boots, sailboards, surfboards, requisites for fishing and hunting, leather sports gloves, sports headgear, ice skates, bows, gymnasium, fitness centre or athletic equipment. In the Chinese market, the National Bureau of Statistics revised the classification standard of the sportsrelated industry in 2019, and defined sports goods in detail, including sports equipment, sports vehicles, aviation sports equipment, sports-related materials, and sports-related goods.

To capture sporting goods words, this study collects product words mentioned in ISIC and China's sports-related industry classification standard. Then, this study uses the method of textual analysis to process the descriptive text in annual reports and obtains some sporting goods words used by China's manufacturing enterprises. Finally, this study deletes the repeated words in these sporting goods words and constructed our sports goods vocabulary containing 481 Chinese sporting goods words.

\subsection{Identification of Sports Goods Manufacturing Enterprise}

Because it is difficult to distinguish what sports goods are provided by enterprises through China's sports-related industry classification, the existing industry classification standard cannot identify sports goods manufacturing enterprises. To address this problem, this study uses the sports goods vocabulary mentioned in Section 3.1 to analyze the annual reports of manufacturing enterprises and obtain the sports goods manufacturing enterprises by providing some sporting goods words in their annual reports.

In this identifying process, this study uses the method of text segmentation to process the descriptive text in the annual reports of manufacturing enterprises and compares the text results with our sports goods dictionary. If firm A uses some sporting goods words in information disclosure, it indicates that firm A provides these products. According to this identifying process, this study identifies the enterprises that provide sports goods in China's listed manufacturing enterprises, and thus constructs a sample of sports goods manufacturing enterprises.

\subsection{Computation of Sports Goods Market Competition}

Based on sports goods vocabulary, this study uses the word vector method to show the products provided by sports goods manufacturing enterprises. In the process of constructing a word vector, this paper constructs a vector for firm i, and each dimension of this vector corresponds to a sporting goods word. In the annual reports of enterprises, managers may repeatedly use the same sporting goods words, which will influence the computation of product similarity between enterprises. Therefore, this paper adopts the method of "total frequency/ inverse document frequency" (TF-IDF) to obtain the weight of each word in the vector of firm $i$.

Through the method of TF-IDF, the value of each word in the word vector is no longer the word's frequency in firm i's annual report, and a word used more frequently in firm i's own report can be populated with a higher weight. TF refers to the frequency of a sporting goods word in firm i's annual report, and IDF refers to the total number of annual reports containing this sporting goods word. The calculation of TF-IDF for word $\mathrm{w}$ is as follows:

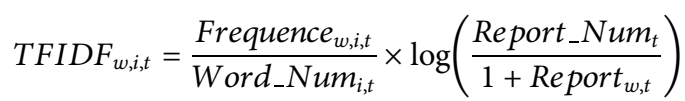

In Eq. 1, TFIDF $F_{w, i, t}$ is the TF-IDF weight of word w; Frequence $_{w, i, t}$ is the frequency of word $w$ in firm i's annual report in year t; Word_Numi,t is the total words of firm i's

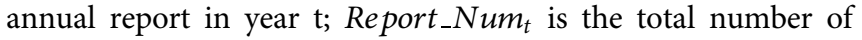
annual reports in year $t$; Report f $_{w, t}$ is the total number of annual reports containing word $w$ in year $\mathrm{t}$.

After computing TF-IDF weights, this study further obtains the weights of sporting goods words in the word vector of firm $i$ in year $\mathrm{t}$ :

$$
\operatorname{Sport}_{i, t}=\left[T F I D F_{w_{1}, i, t}, T F I D F_{w_{2}, i, t}, \ldots, T F I D F_{w_{m}, i, t}\right]
$$

In Eq. 2, TFIDF $F_{w_{m}, i, t}$ is the TF-IDF weight of the $\mathrm{m}$-th word in our sports goods vocabulary for firm i in year t. According to the size of $t$ sports goods vocabulary, this study sets $\mathrm{m}$ as 481 , and each sports goods manufacturing enterprise corresponds to a word vector in which the dimension size is 481 .

From the method of Hoberg and Phillips (2016), the product similarity between sports goods manufacturing enterprises can be displayed by the similarity degree between firm i's word vector and firm j's word vector (Hoberg and Phillips, 2016). Therefore, this study chooses cosine similarity function to measure the similarity between the word vectors of sports goods manufacturing enterprises as follows:

$$
\text { Similarit }_{i, j, t}=\cos \left(\operatorname{Sport}_{i, t}, \operatorname{Sport}_{j, t}\right)=\frac{\operatorname{Sport}_{i, t} \cdot \operatorname{Sport}_{j, t}}{\left\|\operatorname{Sport}_{i, t}\right\| \times\left\|\operatorname{Sport}_{j, t}\right\|}
$$

In Eq. 3, Similarit $y_{i, j, t}$ is the degree of product similarity between firm $i$ and firms $j$ in year $t$; Sport $_{i, t}$ is the word vector of firm $i$ in year $t ; \|$ Sport $_{i, t} \|$ is the length of the word vector of firm $i$ in year t. Based on Eq. 3, this study computes the sports goods similarity results for each firm, and obtains the product similarity set of firm $i$ in year $t$ :

Product_Sim $_{i, t}=\left\{\right.$ Similarit $_{i, 1, t}$, Similarit $y_{i, 2, t}, \ldots$, Similarit $\left._{i, n, t}\right\}$

In our assumption, the increase of product homogeneity will aggravate the competition among sports goods manufacturing enterprises. Moreover, it is difficult for managers to pay attention to all rivals in the products market, which indicates that only some enterprises can bring competitive pressure to managers. 
Referring to the method of Lee et al. (2015), this study defines the closest $\mathrm{k}$ firms as the rivals of firm i, and measures the degree of competition faced by firm i (Lee et al., 2015).

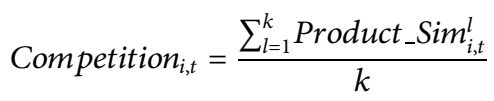

In Eq. 5, Competition $i, t$ is to the degree of sports goods market competition faced by firm i in year t; Product_Sim ${ }_{i, t}^{l}$ is the product similarity between firm $i$ and the l-th rank firm in firm i's product similarity set. According to this method, this study calculates the degree of sports goods market competition faced by any sports goods manufacturing enterprise.

\section{EMPIRICAL MODEL}

\subsection{Data Source}

The research sample of this study is comprised of China's listed manufacturing enterprises in Shenzhen Stock Exchange and Shanghai Stock Exchange from 2010 to 2018. In the Chinese market, private sports goods manufacturing enterprises are small, and these enterprises are difficult to produce sports related products for a long time. Compared with private enterprises, listed enterprises not only have sufficient internal and sales resources, but also need to introduce sports-related products in detail in their annual reports. Therefore, this study chooses listed sports goods manufacturing enterprises as research samples. In terms of text data, this study extracts the section of Management Discussion and Analysis (MD\&A) from the annual reports of listed manufacturing enterprises. Under the requirements of the China Securities Regulatory Commission, China's listed enterprises need to introduce their main business and products in the section of MD\&A, and need to introduce their future product planning in this section. Therefore, this study collects the annual reports of China's manufacturing enterprises from 2010 to 2018, and transforms these annual reports into txt file format, to obtain the descriptive text contained in this section.

In terms of industrial policy, this study uses the method of manual search to obtain the policy documents related to sportsrelated industry from the Chinese government website from 2010 to 2018, including the website of the State Council of China, the website of the General Administration of Sport of China, the website of the Ministry of Education of China. Finally, this study selects 27 sports-related industrial policies, and the list of these policies is in Supplementary Table S1.

In terms of green innovation, this study uses the number of green patent applications to measure the investment in green innovation. The data of green patent applications is obtained from the green patent database of Chinese Research Data Services Platform (CNRDS). CNRDS collects the green patent data of China's listed companies according to the green patent classification standards provided by the China National Intellectual Property Administration and the World Intellectual Property Organization. The data of corporate finance and governance is derived from China Stock Market and Accounting Research Database (CSMAR). All continuous variables are winsorized at $1 \%$ at both tails, which can minimize the influence of extreme values in empirical analysis. Finally, this study obtains 2,119 observations of sports goods manufacturing enterprises in the Chinese market.

\subsection{Construction of Variables}

\subsubsection{Dependent Variable}

Green innovation is an important tool to measure the efforts of enterprises in energy conservation and environmental protection. In sports goods manufacturing enterprises, green innovation can be demonstrated through the outcomes of green technology, which will create more environmental benefits and economic profitability. Referring to the measurement of Li et al. (2017), this study uses the number of green patent applications to measure the green innovation of sports goods manufacturing enterprises (Li et al., 2017).

\subsubsection{Independent Variables}

Product market competition reflects the competitive environment faced by sports goods manufacturing enterprises. Compared with the traditional measurement of competition, this study uses the method of textual analysis to build a unique competitive environment for each sports goods manufacturing enterprise, and measures the similarity of products among such enterprises. Referring to Lee et al. (2015), this study sets the $\mathrm{k}$ in Eq. 5 as 10 - that each sports goods manufacturing enterprise will face 10 rivals with the highest product similarity (Lee et al., 2015). Therefore, this study uses the method proposed by Eq. 5 to measure the degree of product market competition for each sports goods manufacturing enterprise.

The industrial policy reflects the degree of government support for sports-related industries, and this kind of policy may also be affected by international sporting events. In the Chinese market, the "Guiding Opinions on Accelerating the Development of Sports Industry" published in 2010 has become a landmark in promoting the development of the sports goods manufacturing industries. For the 2022 Beijing Winter Olympic Games, the Chinese government has issued many sports-related industrial policies, which also improve the demand of winter sports goods. Furthermore, more industrial policies can also force sports goods manufacturing enterprises to pay more attention to their products or change their portfolio of products. According to the theory of industrial organization, the change of product portfolio will alter the product differentiation among enterprises, which further affects the preference of managers to enter some new product markets. Based on this, industrial policy may change the competition intensity among sports goods manufacturing enterprises. We manually read all sportsrelated policies from 2010 to 2018, and select some policies mentioned the development of sports goods manufacturing industries, so as to better capture the government's attention to such industries. Therefore, this study uses the number of sports-related industrial policies published in year $t$ to measure industrial policy. 
TABLE 1 | The definition of variables.

\begin{tabular}{|c|c|c|}
\hline Type & Variable & Definition \\
\hline Dependent Variable & Green Innovation & Green Innovation is measured by the number of green patent applications \\
\hline Independent Variable & $\begin{array}{l}\text { Competition } \\
\text { Policy }\end{array}$ & $\begin{array}{l}\text { Competition is calculated as the result of sports goods market competition in Eq. } 5 \\
\text { Policy is measured by the number of sports-related industrial policies }\end{array}$ \\
\hline Control Variable & $\begin{array}{l}\text { ROA } \\
\text { Liquidity } \\
\text { Growth } \\
\text { Return } \\
\text { Subsidy } \\
\text { Age } \\
\text { Hold } \\
\text { Independ }\end{array}$ & $\begin{array}{l}\text { ROA is calculated as the net income divided by total assets } \\
\text { Liquidity is calculated as the current assets divided by total assets } \\
\text { Growth is calculated as the growth radio of operating revenues } \\
\text { Return is measured by the yearly cum-dividend return } \\
\text { Subsidy is calculated as the government subsidies divided by total assets } \\
\text { Age is the duration from the established year to the sample year } \\
\text { Hold is the sum of shareholdings of the top ten shareholders } \\
\text { Independ is calculated as the number of independent directors }\end{array}$ \\
\hline
\end{tabular}

\subsubsection{Control Variables}

This study selects control variables from financial characteristics, stock market performance, and governance characteristics, which may have a potential impact on green innovation (Chen, 2008; Amore and Bennedsen, 2016; Zhang et al., 2020; Oduro et al., 2021). The control variables include Return on assets, Current assets, Company growth, Stock return, Government subsidies, Firm age, Shareholding of the top ten shareholders, and Independent directors. Return on assets (ROA) represents the profitability of manufacturing enterprises of sports goods. Current assets (Liquidity) represents the current assets ratio of the manufacturing enterprises of sports goods. Company growth (Growth) represents the growth potential of the manufacturing enterprises of sports goods. Stock return (Return) represents the stock performance of the manufacturing enterprises of sports goods. Government subsidies (Subsidy) represents the local government support of the manufacturing enterprises of sports goods. Firm age (Age) is the duration from the established year to the sample year. Shareholdings of the top ten shareholders (Hold) represent the ownership concentration. Independent directors (Independ) represent the board structure.

The definitions of different variables are provided in Table $\mathbf{1}$.

\subsection{Construction of Model}

During the process of empirical analysis, this study discusses whether the green innovation of sports goods manufacturing enterprises can be affected by product market competition or industrial policies. Firstly, this study explores the direct impact of product market competition and industrial policy on green innovation. Refer to Jiang et al. (2018), different factors may influence innovation outcomes for a long time, so that the association between driving factors and green innovation could not be captured at the same period (Jiang et al., 2018). Based on this, the independent variables and the control variables lag 1 year respectively, and the year dummy variable and the industry dummy variable are introduced into the empirical models to control the effects of time and group. The basic empirical model is as follows:

$$
\begin{aligned}
\text { Green Innovation }_{i, t} & =\alpha_{0}+\beta_{1} \text { Competition }_{i, t-1}+\beta_{2} \text { Polic }_{t-1} \\
& +\beta_{3} \text { ROA }_{i, t-1}+\beta_{4} \text { Liquidit }_{i, t-1}+\beta_{5} \text { Growt }_{i, t-1} \\
& +\beta_{6} \text { Return }_{i, t-1}+\beta_{7} \text { Subsid }_{i, t-1}+\beta_{8} \text { Age }_{i, t-1} \\
& +\beta_{9} \text { Hold }_{i, t-1}+\beta_{10} \text { Independ }_{i, t-1}+\text { Year }_{\text {fixed }} \\
& + \text { Industr }_{\text {fixed }}+\varepsilon
\end{aligned}
$$

In Eq. 6, Green Innovation $_{i, t}$ is the green innovation of firm i in year t. Competition Cot $_{i-1}$ is the product market competition of firm $\mathrm{i}$ in year $\mathrm{t}-1$; Polic $y_{t-1}$ is the industrial policy in year $\mathrm{t}-1$; $R O A_{i, t-1}$ is the profitability of firm $\mathrm{i}$ in year $\mathrm{t}-1$. Liquidit $y_{i, t-1}$ is the current assets of firms $i$ in year $\mathrm{t}-1$; Growt $_{i, t-1}$ is the growing operating revenues of firm i in year t-1; Return $n_{i, t-1}$ is the yearly cum-dividend return of firm $\mathrm{i}$ in year $\mathrm{t}-1$; Subsidy $y_{i, t-1}$ is the government subsidies of firm i in year t-1; $A g e_{i, t-1}$ is the duration of firm i in year $\mathrm{t}-1$; Hold $_{i, t-1}$ is the ownership concentration of firm i in year $\mathrm{t}-1$; Independ $_{i, t-1}$ is the board structure of firm $\mathrm{i}$ in year t-1. Year $_{\text {fixed }}$ and Industr $y_{\text {fixed }}$ are the time dummy variable and the industry dummy variable. $\varepsilon$ is the error term.

$$
\begin{aligned}
\text { Green Innovation }_{i, t}= & \alpha_{0}+\beta_{1} \text { Competition }_{i, t-1}+\beta_{2} \text { Polic }_{t-1} \\
& +\beta_{3} \text { Competition }_{i, t-1} \times \text { Polic }_{t-1}+\beta_{4} \text { ROA }_{i, t-1} \\
& +\beta_{5} \text { Liquidit }_{i, t-1}+\beta_{6} \text { Growth }_{i, t-1} \\
& +\beta_{7} \text { Return }_{i, t-1}+\beta_{8} \text { Subsid }_{i, t-1}+\beta_{9} \text { Age }_{i, t-1} \\
& +\beta_{10} \text { Hold }_{i, t-1}+\beta_{11} \text { Independ }_{i, t-1}+\text { Year }_{\text {fixed }} \\
& + \text { Industr }_{\text {fixed }}+\mathcal{\varepsilon}
\end{aligned}
$$

From the resource-based view, the relationship between market competition and enterprise innovation may be affected by macro policy, indicating that industrial policy may have a moderating role in this relationship. Therefore, this study introduces the interaction term of product market competition and industrial policy (Competition ${ }_{i, t-1} \times$ Polic $_{t-1}$ ) into Eq. 6 . Eq. 7 will be used to test Hypothesis 3 proposed in section 2.4.

\section{EMPIRICAL RESULTS}

\subsection{Descriptive Statistics}

Table 2 provides the results of descriptive statistics for all variables in empirical models constructed in section 4.3. The 
TABLE 2 | The results of descriptive statistics.

\begin{tabular}{|c|c|c|c|c|c|c|}
\hline Variables & Observations & Mean & Standard Deviation & Min & Median & Max \\
\hline Green Innovation & 2,119 & 4.9533 & 17.7506 & 0.0000 & 0.0000 & 310.0000 \\
\hline Competition & 2,119 & 0.6997 & 0.2832 & 0.0000 & 0.7554 & 1.0000 \\
\hline Policy & 2,119 & 3.6182 & 4.2444 & 0.0000 & 2.0000 & 14.0000 \\
\hline $\mathrm{ROA}$ & 2,119 & 0.0390 & 0.0635 & -0.2726 & 0.0382 & 0.1880 \\
\hline Liquidity & 2,119 & 0.5777 & 0.1641 & 0.1995 & 0.5812 & 0.9194 \\
\hline Growth & 2,119 & 0.2197 & 0.6360 & -0.7008 & 0.0872 & 4.3950 \\
\hline Return & 2,119 & 0.0798 & 0.5355 & -0.5992 & -0.0119 & 2.4283 \\
\hline Subsidy & 2,119 & 0.0032 & 0.0124 & 0.0000 & 0.0000 & 0.3377 \\
\hline Age & 2,119 & 2.6934 & 0.3953 & 1.3863 & 2.7726 & 3.4012 \\
\hline Hold & 2,119 & 0.5946 & 0.1521 & 0.1102 & 0.6035 & 0.9712 \\
\hline Independ & 2,119 & 3.1269 & 0.5509 & 0.0000 & 3.0000 & 7.0000 \\
\hline
\end{tabular}

\begin{tabular}{|c|c|c|c|c|c|c|}
\hline Variables & Green innovation & Competition & Policy & ROA & Liquidity & VIF \\
\hline Green Innovation & - & $0.056^{\star \star \star}$ & $0.071^{\star \star \star}$ & $-0.048^{\star \star}$ & -0.018 & \\
\hline Competition & $0.045^{\star \star}$ & - & $0.121^{\star \star \star}$ & $0.041^{*}$ & -0.010 & 1.02 \\
\hline Policy & $0.018^{\star \star \star}$ & $0.085^{\star \star \star}$ & - & 0.015 & -0.022 & 1.16 \\
\hline $\mathrm{ROA}$ & 0.010 & 0.036 & 0.015 & - & $0.286^{\star \star \star}$ & 1.19 \\
\hline Liquidity & 0.008 & -0.004 & $-0.037^{\star}$ & $0.255^{\star \star \star}$ & - & 1.10 \\
\hline Growth & -0.016 & $-0.043^{\star \star}$ & $0.056^{\star \star}$ & -0.008 & $0.075^{\star \star \star}$ & 1.04 \\
\hline Return & 0.012 & -0.034 & $-0.304^{\star \star \star}$ & $0.085^{\star \star \star}$ & 0.003 & 1.13 \\
\hline Subsidy & 0.001 & $-0.057^{\star \star \star}$ & 0.004 & $0.060^{\star \star \star}$ & -0.036 & 1.04 \\
\hline Age & $0.063^{\star \star \star}$ & $0.041^{\star}$ & $0.178^{\star \star \star}$ & $-0.100^{\star \star \star}$ & $-0.118^{\star \star \star}$ & 1.12 \\
\hline Hold & -0.025 & 0.029 & 0.007 & $0.312^{\star \star \star}$ & $0.153^{\star \star \star}$ & 1.20 \\
\hline Independ & $0.124^{\star \star \star}$ & -0.018 & $-0.038^{\star}$ & 0.024 & $-0.043^{\star \star}$ & 1.01 \\
\hline Variables & Growth & Return & Subsidy & Age & Hold & Independ \\
\hline Green Innovation & $0.044^{\star \star}$ & -0.007 & -0.022 & $0.062^{\star \star \star}$ & $-0.081^{\star \star \star}$ & $0.051^{\star \star}$ \\
\hline Competition & -0.014 & $-0.036^{\star}$ & -0.024 & 0.026 & 0.012 & -0.031 \\
\hline Policy & $0.056^{\star \star}$ & $-0.480^{\star \star \star}$ & $-0.177^{\star \star \star}$ & $0.229^{\star \star \star}$ & $0.041^{\star}$ & $-0.038^{*}$ \\
\hline $\mathrm{ROA}$ & -0.018 & $0.122^{\star \star \star}$ & -0.031 & $-0.098^{\star \star \star}$ & $0.352^{\star \star \star}$ & -0.007 \\
\hline Liquidity & $0.123^{\star \star \star}$ & 0.011 & $-0.047^{\star \star}$ & $-0.112^{\star \star \star}$ & $0.150^{\star \star \star}$ & $-0.039^{*}$ \\
\hline Growth & - & 0.032 & 0.018 & $-0.054^{\star \star}$ & 0.008 & 0.019 \\
\hline Return & $0.070^{\star \star \star}$ & - & $0.195^{\star \star \star}$ & $-0.131^{\star \star \star}$ & -0.010 & 0.004 \\
\hline Subsidy & $0.121^{\star \star \star}$ & $0.060^{\star \star \star}$ & - & $-0.159^{\star \star \star}$ & $-0.080^{\star \star \star}$ & -0.023 \\
\hline Age & -0.034 & $-0.098^{\star \star \star}$ & -0.019 & - & $-0.248^{\star \star \star}$ & $0.046^{\star \star}$ \\
\hline Hold & 0.002 & -0.026 & $-0.075^{\star \star \star}$ & $-0.249^{\star \star \star}$ & - & 0.019 \\
\hline Independ & 0.034 & -0.025 & -0.030 & 0.026 & $0.043^{*}$ & - \\
\hline
\end{tabular}

Note: ***, **, ${ }^{*}$ Represent the significance at the level of 1, 5, 10\% respectively. Pearson correlations among variables are below the diagonal; Spearman correlations among all variables are above the diagonal.

mean of green innovation is 4.9533 , and its standard deviation is 17.7506, indicating that there are great differences between sports goods manufacturing enterprises in green innovation. The mean and median of product market competition are 0.6997 and 0.7554 respectively, which indicates that many sports goods manufacturing enterprises will face a highly competitive market. The standard deviation of product market competition is 0.2832 , demonstrating that the difference in competitive environment faced by sports goods manufacturing enterprises is small. In terms of industrial policy, its standard deviation is 4.2444, indicating that there are huge differences in sports-related policies from 2010 to 2018 . For control variables, the minimum ROA is -0.2726 , which indicates that some sports goods manufacturing enterprises fall into financial distress. The mean of Liquidity is 0.5777 , and its standard deviation is 0.1641 , which indicates that the distribution of current assets rate of sports goods manufacturing enterprises is relatively balanced. The mean of Growth is 0.2197 , and its standard deviation is 0.6360 , indicating that there are great differences in the development of sports goods manufacturing enterprises. The median of Return is -0.0119 , which indicates that many sports goods manufacturing enterprises have poor profitability. The mean and median of Subsidy are 0.0032 and 0.0000 respectively, demonstrating that many sports goods manufacturing enterprises cannot obtain government subsidies. The maximum of hold is 0.9712 , which indicates that some sporting goods enterprises have the problem of over-concentration of shares. The mean and median of 
TABLE 4 | Baseline results of overall samples.

\begin{tabular}{|c|c|c|c|c|c|c|}
\hline \multirow[t]{2}{*}{ Variables } & \multicolumn{6}{|c|}{ Green innovation } \\
\hline & (1) & (2) & (3) & (4) & (5) & (6) \\
\hline Competition & $\begin{array}{c}0.8807^{\star \star} \\
(2.37)\end{array}$ & & $\begin{array}{c}1.1232^{\star \star \star} \\
(3.27)\end{array}$ & & $\begin{array}{c}1.1232^{\star \star \star} \\
(3.27)\end{array}$ & $\begin{array}{c}1.1858^{\star \star \star} \\
(3.40)\end{array}$ \\
\hline Policy & & $\begin{array}{c}2.1751^{\star \star \star} \\
(4.23)\end{array}$ & & $\begin{array}{c}2.5804^{\star \star \star} \\
(5.67)\end{array}$ & $\begin{array}{c}2.3267^{\star \star \star} \\
(5.11)\end{array}$ & $\begin{array}{c}2.3601^{\star \star *} \\
(5.22)\end{array}$ \\
\hline Competition * Policy & & & & & & $\begin{array}{c}0.0681^{\star} \\
(1.69)\end{array}$ \\
\hline $\mathrm{ROA}$ & & & $\begin{array}{c}-0.5585 \\
(-0.23)\end{array}$ & $\begin{array}{c}-0.5351 \\
(-0.21)\end{array}$ & $\begin{array}{c}-0.5585 \\
(-0.23)\end{array}$ & $\begin{array}{c}-0.5414 \\
(-0.23)\end{array}$ \\
\hline Liquidity & & & $\begin{array}{c}-1.2703^{\star} \\
(-1.83)\end{array}$ & $\begin{array}{c}-1.1670 \\
(-1.59)\end{array}$ & $\begin{array}{c}-1.2703^{*} \\
(-1.83)\end{array}$ & $\begin{array}{c}-1.2408^{*} \\
(-1.79)\end{array}$ \\
\hline Growth & & & $\begin{array}{c}-0.0137 \\
(-0.11)\end{array}$ & $\begin{array}{c}-0.0240 \\
(-0.18)\end{array}$ & $\begin{array}{c}-0.0137 \\
(-0.11)\end{array}$ & $\begin{array}{c}-0.0052 \\
(-0.04)\end{array}$ \\
\hline Return & & & $\begin{array}{c}0.4541^{\star \star \star} \\
(2.91)\end{array}$ & $\begin{array}{c}0.4928^{\star \star \star} \\
(3.12)\end{array}$ & $\begin{array}{c}0.4541^{\star \star \star} \\
(2.91)\end{array}$ & $\begin{array}{c}0.4549^{\star \star \star} \\
(2.93)\end{array}$ \\
\hline Subsidy & & & $\begin{array}{c}2.0029 \\
(0.46)\end{array}$ & $\begin{array}{c}3.0279 \\
(0.32)\end{array}$ & $\begin{array}{c}2.0029 \\
(0.46)\end{array}$ & $\begin{array}{c}3.0692 \\
(0.72)\end{array}$ \\
\hline Age & & & $\begin{array}{c}-0.7144^{\star *} \\
(-2.14)\end{array}$ & $\begin{array}{c}-0.6218^{*} \\
(-1.83)\end{array}$ & $\begin{array}{c}-0.7144^{\star \star} \\
(-2.14)\end{array}$ & $\begin{array}{c}-0.7132^{\star \star} \\
(-2.15)\end{array}$ \\
\hline Hold & & & $\begin{array}{c}0.2127 \\
(0.27)\end{array}$ & $\begin{array}{c}0.0234 \\
(0.03)\end{array}$ & $\begin{array}{c}0.2127 \\
(0.27)\end{array}$ & $\begin{array}{c}0.1978 \\
(0.25)\end{array}$ \\
\hline Independ & & & $\begin{array}{c}0.4031^{\star \star} \\
(2.15)\end{array}$ & $\begin{array}{c}0.3866^{\star *} \\
(2.02)\end{array}$ & $\begin{array}{c}0.4031^{* *} \\
(2.15)\end{array}$ & $\begin{array}{c}0.4040^{\star \star} \\
(2.17)\end{array}$ \\
\hline Constant & $\begin{array}{c}-1.9076^{\star \star \star} \\
(-2.97)\end{array}$ & $\begin{array}{c}-3.5191^{\star \star \star} \\
(-3.39)\end{array}$ & $\begin{array}{c}-1.2320 \\
(-0.88)\end{array}$ & $\begin{array}{c}-3.2379^{\star *} \\
(-2.20)\end{array}$ & $\begin{array}{c}-3.5586^{\star \star} \\
(-2.43)\end{array}$ & $\begin{array}{c}-3.6688^{\star \star} \\
(-2.51)\end{array}$ \\
\hline Year & Yes & Yes & Yes & Yes & Yes & Yes \\
\hline Industry & Yes & Yes & Yes & Yes & Yes & Yes \\
\hline Observations & 2,119 & 2,119 & 2,119 & 2,119 & 2,119 & 2,119 \\
\hline Wald $\chi^{2}$ & 113.33 & 104.88 & 187.22 & 183.71 & 187.22 & 188.87 \\
\hline Pseudo $R^{2}$ & 0.0478 & 0.0456 & 0.0567 & 0.0531 & 0.0567 & 0.0570 \\
\hline
\end{tabular}

Note: $Z$ statistics are in parentheses; ${ }^{* * *},{ }^{* *},{ }^{*}$ Represent the significance at the level of $1,5,10 \%$ respectively.

Independ are 0.5946 and 0.6035 respectively, demonstrating that the distribution of independent directors is balanced.

Before the empirical analysis, this study analyzes the correlation of variables used in empirical models, and obtains the correlation matrix of Pearson and Spearman. In Table 3, the correlation coefficients between Competition and Green Innovation are 0.045 and 0.056 respectively, significant at the $5 \%$ level and $1 \%$ level, indicating a positive association between product market competition and green innovation outcomes. The correlation coefficients between Policy and Green Innovation are 0.018 and 0.071 respectively, significant at the $1 \%$ level, indicating a positive association between sports-related industry policies and green innovation outcomes. From the results of control variables, the absolute correlation coefficients between the control variables and independent variables or Green Innovation are less than 0.5 , indicating that there is no collinearity problem in empirical models. Furthermore, this study uses the VIF method to test whether there is a multicollinearity problem in empirical models. According to the results of VIF, the VIF values of independent variables and control variables are less than 2 , demonstrating that there is no multicollinearity problem in empirical models.

\subsection{Baseline Test}

To explore the driving factors of green innovation, this study adopts the empirical models constructed by Eq. 6 and Eq. 7 to test the research hypothesis proposed in Section 2. Firstly, this study explores the impact of product market competition or industrial policy on the green innovation of sports goods manufacturing enterprises without considering control variables. Then, this study introduces control variables into regression analysis, and explores the relationship among product market competition, industrial policy, and green innovation. Finally, this study introduces the interaction between product market competition and industrial policy into empirical analysis, and further explores the role of industrial policy in moderating the relationship between product market competition and the green innovation of sports goods manufacturing enterprises. The baseline results are reported in Table 4.

In Table 4, Columns (1) and (2) respectively examine the impact of product market competition and industrial policy on green innovation without considering control variables. In Column (1), the competition coefficient is 0.8807 , significant at the $5 \%$ level, indicating a significant positive association between product market competition and green innovation. In Column (2), the coefficient of industrial policy is 2.1751, significant at the $1 \%$ level, indicating a significant positive association between industrial policy and green innovation. Column (3)-(5) explore the relationship among product market competition, industrial policy, and green innovation under the condition of considering control variables. In 
TABLE 5 | Results of different financial constraints.

\begin{tabular}{|c|c|c|c|c|}
\hline \multirow[t]{3}{*}{ Variables } & \multicolumn{4}{|c|}{ Green innovation } \\
\hline & \multicolumn{2}{|c|}{ Low constraints } & \multicolumn{2}{|c|}{ High constraints } \\
\hline & (1) & (2) & (3) & (4) \\
\hline Competition & $\begin{array}{c}1.1450^{\star \star \star} \\
(2.78)\end{array}$ & $\begin{array}{c}1.3640^{\star \star \star} \\
(3.09)\end{array}$ & $\begin{array}{c}-0.6971^{\star} \\
(-1.90)\end{array}$ & $\begin{array}{c}-0.7132^{*} \\
(-1.94)\end{array}$ \\
\hline Policy & $\begin{array}{c}3.2989^{\star \star \star} \\
(6.06)\end{array}$ & $\begin{array}{c}3.3105^{\star \star \star} \\
(6.07)\end{array}$ & $\begin{array}{c}1.1717^{\star} \\
(1.92)\end{array}$ & $\begin{array}{c}1.1444^{\star} \\
(1.87)\end{array}$ \\
\hline Competition * Policy & & $\begin{array}{c}0.1429^{\star \star} \\
(2.44)\end{array}$ & & $\begin{array}{c}-0.0464 \\
(-0.78)\end{array}$ \\
\hline $\mathrm{ROA}$ & $\begin{array}{c}-0.5010 \\
(-0.15)\end{array}$ & $\begin{array}{c}-0.7323 \\
(-0.22)\end{array}$ & $\begin{array}{c}-2.0494 \\
(-0.92)\end{array}$ & $\begin{array}{c}-2.0544 \\
(-0.92)\end{array}$ \\
\hline Liquidity & $\begin{array}{c}-0.9776 \\
(-1.29)\end{array}$ & $\begin{array}{c}-0.9707 \\
(-1.29)\end{array}$ & $\begin{array}{c}-0.4044 \\
(-0.48)\end{array}$ & $\begin{array}{c}-0.4444 \\
(-0.52)\end{array}$ \\
\hline Growth & $\begin{array}{c}-0.1115 \\
(-0.70)\end{array}$ & $\begin{array}{c}-0.0982 \\
(-0.63)\end{array}$ & $\begin{array}{c}0.2521 \\
(0.83)\end{array}$ & $\begin{array}{c}0.2405 \\
(0.78)\end{array}$ \\
\hline Return & $\begin{array}{c}0.5578^{\star \star} \\
(2.49)\end{array}$ & $\begin{array}{c}0.5492^{* \star} \\
(2.45)\end{array}$ & $\begin{array}{c}0.3170 \\
(1.32)\end{array}$ & $\begin{array}{c}0.3179 \\
(1.31)\end{array}$ \\
\hline Subsidy & $\begin{array}{c}20.4048 \\
(1.07)\end{array}$ & $\begin{array}{c}20.4612 \\
(1.10)\end{array}$ & $\begin{array}{c}0.2854 \\
(0.10)\end{array}$ & $\begin{array}{c}-0.4268 \\
(-0.14)\end{array}$ \\
\hline Age & $\begin{array}{c}-0.6191^{\star} \\
(-1.80)\end{array}$ & $\begin{array}{c}-0.6030^{\star} \\
(-1.75)\end{array}$ & $\begin{array}{c}-0.9851^{\star \star \star} \\
(-2.77)\end{array}$ & $\begin{array}{c}-0.9681^{\text {**> }} \\
(-2.71)\end{array}$ \\
\hline Hold & $\begin{array}{c}-0.0347 \\
(-0.04)\end{array}$ & $\begin{array}{c}0.0249 \\
(0.03)\end{array}$ & $\begin{array}{c}-0.7992 \\
(-0.76)\end{array}$ & $\begin{array}{c}-0.7276 \\
(-0.68)\end{array}$ \\
\hline Independ & $\begin{array}{c}0.3205^{\star} \\
(1.83)\end{array}$ & $\begin{array}{c}0.3238^{\star} \\
(1.87)\end{array}$ & $\begin{array}{c}-0.1530 \\
(-0.61)\end{array}$ & $\begin{array}{c}-0.1563 \\
(-0.62)\end{array}$ \\
\hline Constant & $\begin{array}{c}-5.0848^{\star \star \star} \\
(-3.17)\end{array}$ & $\begin{array}{c}-5.3367^{\star \star \star} \\
(-3.29)\end{array}$ & $\begin{array}{c}0.6361 \\
(0.37)\end{array}$ & $\begin{array}{c}0.6431 \\
(0.37)\end{array}$ \\
\hline Year & Yes & Yes & Yes & Yes \\
\hline Industry & Yes & Yes & Yes & Yes \\
\hline Observations & 1,062 & 1,062 & 1,057 & 1,057 \\
\hline Wald $\chi^{2}$ & 196.95 & 201.38 & 310.00 & 312.15 \\
\hline Pseudo $R^{2}$ & 0.0612 & 0.0621 & 0.0735 & 0.0737 \\
\hline
\end{tabular}

Note: Z statistics are in parentheses; ${ }^{* * *}$, **, ${ }^{*}$ Represent the significance at the level of 1,5 , $10 \%$ respectively.

Columns (3) and (4), the results of the competition and industrial policy are consistent with those in Columns (1) and (2), which indicates that product market competition or industrial policy can promote green innovation of sports goods manufacturing enterprises. In Column (5), the coefficients of competition and industrial policy are 1.1232 and 2.3267 separately, significant at the $1 \%$ level, indicating that product market competition and industrial policy can both promote the efforts of sports goods manufacturing enterprises in green innovation. Based on the empirical results of Columns (1)-(5), product market competition and industrial policy can be the driving factors of green innovation in sports goods manufacturing industries. Thus, $\mathrm{H} 1 \mathrm{a}$ and $\mathrm{H} 2 \mathrm{a}$ are supported. Column (6) further explores the moderating role of industrial policy in the relationship between product market competition and green innovation. In Column (6), interaction term coefficient (Competition * Policy) is 0.0681 , significant at the $10 \%$ level. The results of Column (6) demonstrates that industrial policy can moderate the positive association between product market competition and green innovation, which supports $\mathrm{H} 3$ proposed in Section 2.4. According to the empirical results in Table 4, product market competition and industry policy can promote the investment of sports goods manufacturing enterprises in green innovation, and the association between competition and green innovation will be moderated by macro policy, which can explain why such enterprises need to rely on green innovation outcomes to obtain unique competitive advantages.

\subsection{Heterogeneity Test}

\subsubsection{The Test of Financial Constraint}

Sports goods manufacturing enterprises rely on external finance to support their $\mathrm{R} \& \mathrm{D}$ activities. In this situation, different financial constraints will change the efforts of sports goods manufacturing enterprises in green innovation. Referring to the method of Hadlock and Pierce (2010), this study uses SA index to measure the level of financial constraints faced by sports goods manufacturing enterprises (Hadlock and Pierce, 2010). The research sample is divided into two subsamples based on the SA index: the low financial constraints subsamples (SA index is higher than the median) and the high financial constraints subsample (SA index is lower than the median). In different subsamples, this study still uses the empirical models constructed by Eq. 6 and Eq. 7, and the empirical results are reported in Table 5.

In Table 5, Columns (1) and (2) discuss the impact of product market competition and industrial policy on the green innovation of sports goods manufacturing enterprises with low financial constraints. In Column (1), the coefficients of Competition and Policy are 1.1450 and 3.2989 independently, significant at the $1 \%$ level. In Column (2), the interaction term coefficient (Competition * Policy) is 0.1429 , significant at the $5 \%$ level, indicating that industrial policy can strengthen the positive association between product market competition and green innovation in sports goods manufacturing industries. Columns (3) and (4) explore the impact of product market competition and industrial policy on the green innovation of sports goods manufacturing enterprises with high financing constraints. In Column (3), the coefficients of Competition and Policy are -0.6971 and 1.1717 respectively, significant at the $10 \%$ level, indicating that the highly competitive environment could inhibit the green innovation of enterprises under the condition of high financial constraints. In Column (4), interaction term coefficient (Competition * Policy) is -0.0464 , which indicates that the inhibition of product market competition on the green innovation of such enterprises may come from too many industrial policies. According to the empirical results in Table 5, when sports goods manufacturing enterprises are faced with high financial constraints, the highly competitive environment created by industrial policies may force managers to give up the investment in green innovation.

\subsubsection{The Test of Environmental Policy}

The efforts of sports goods manufacturing enterprises in green innovation may also be affected by environmental policies. With the proposal of a sustainable development strategy, the Chinese government has been upgrading the industrial structure of the manufacturing industry for a long time and has enacted some strict environmental policies for reducing the pollutant emission of manufacturing enterprises. In 2014, China's Ministry of Ecology and Environment modified The Environmental Protection Law and 
TABLE 6 | Results of different periods.

\begin{tabular}{|c|c|c|c|c|}
\hline \multirow[t]{3}{*}{ Variables } & \multicolumn{4}{|c|}{ Green innovation } \\
\hline & \multicolumn{2}{|c|}{ Before 2014} & \multicolumn{2}{|c|}{ After 2014} \\
\hline & (1) & (2) & (3) & (4) \\
\hline Competition & $\begin{array}{c}0.8035 \\
(1.44)\end{array}$ & $\begin{array}{c}-2.3517^{\star} \\
(-1.65)\end{array}$ & $\begin{array}{c}1.1378^{\star \star \star} \\
(3.14)\end{array}$ & $\begin{array}{c}1.1799^{\star \star \star} \\
(3.27)\end{array}$ \\
\hline Policy & $\begin{array}{c}1.3010^{\star \star \star} \\
(2.79)\end{array}$ & $\begin{array}{c}1.2395^{\star \star \star} \\
(2.69)\end{array}$ & $\begin{array}{c}0.0768^{\star \star \star} \\
(3.78)\end{array}$ & $\begin{array}{c}0.0759^{* \star *} \\
(3.72)\end{array}$ \\
\hline Competition * Policy & & $\begin{array}{c}-1.2986^{\star \star \star} \\
(-2.73)\end{array}$ & & $\begin{array}{c}0.0720^{\star \star} \\
(1.98)\end{array}$ \\
\hline $\mathrm{ROA}$ & $\begin{array}{c}-9.7717^{\star \star \star} \\
(-3.10)\end{array}$ & $\begin{array}{c}-9.8864^{\star \star \star} \\
(-3.26)\end{array}$ & $\begin{array}{c}2.9985 \\
(1.14)\end{array}$ & $\begin{array}{c}2.9895 \\
(1.15)\end{array}$ \\
\hline Liquidity & $\begin{array}{c}-1.1652 \\
(-1.24)\end{array}$ & $\begin{array}{c}-1.3723 \\
(-1.57)\end{array}$ & $\begin{array}{c}-1.3281^{*} \\
(-1.69)\end{array}$ & $\begin{array}{r}-1.2811 \\
(-1.63)\end{array}$ \\
\hline Growth & $\begin{array}{c}0.2995 \\
(0.96)\end{array}$ & $\begin{array}{c}0.2411 \\
(0.84)\end{array}$ & $\begin{array}{c}0.0074 \\
(0.05)\end{array}$ & $\begin{array}{c}0.0153 \\
(0.11)\end{array}$ \\
\hline Return & $\begin{array}{c}0.3906 \\
(0.65)\end{array}$ & $\begin{array}{c}0.7007 \\
(1.09)\end{array}$ & $\begin{array}{c}0.4722^{\star \star \star} \\
(2.90)\end{array}$ & $\begin{array}{c}0.4720^{\star \star *} \\
(2.91)\end{array}$ \\
\hline Subsidy & $\begin{array}{c}-68.0909^{*} \\
(-1.83)\end{array}$ & $\begin{array}{c}-71.4501^{\star \star} \\
(-2.04)\end{array}$ & $\begin{array}{c}4.7994 \\
(0.67)\end{array}$ & $\begin{array}{c}5.8539 \\
(0.87)\end{array}$ \\
\hline Age & $\begin{array}{c}-1.3385^{\star \star \star} \\
(-3.31)\end{array}$ & $\begin{array}{c}-1.2000^{\star \star \star} \\
(-3.01)\end{array}$ & $\begin{array}{c}-0.5723 \\
(-1.60)\end{array}$ & $\begin{array}{l}-0.5711 \\
(-1.61)\end{array}$ \\
\hline Hold & $\begin{array}{c}0.8071 \\
(0.81)\end{array}$ & $\begin{array}{c}0.9387 \\
(0.95)\end{array}$ & $\begin{array}{c}-0.1885 \\
(-0.21)\end{array}$ & $\begin{array}{c}-0.2033 \\
(-0.23)\end{array}$ \\
\hline Independ & $\begin{array}{c}0.0549 \\
(0.26)\end{array}$ & $\begin{array}{c}0.0200 \\
(0.10)\end{array}$ & $\begin{array}{c}0.3901^{*} \\
(1.92)\end{array}$ & $\begin{array}{c}0.3953^{\star \star} \\
(1.96)\end{array}$ \\
\hline Constant & $\begin{array}{l}0.4446 \\
(0.25)\end{array}$ & $\begin{array}{l}2.7226 \\
(1.40)\end{array}$ & $\begin{array}{c}-0.2060 \\
(-0.14)\end{array}$ & $\begin{array}{r}-0.2627 \\
(-0.18)\end{array}$ \\
\hline Year & Yes & Yes & Yes & Yes \\
\hline Industry & Yes & Yes & Yes & Yes \\
\hline Observations & 635 & 635 & 1,484 & 1,484 \\
\hline Wald $x^{2}$ & 2064.16 & 1821.06 & 137.87 & 141.13 \\
\hline Pseudo $R^{2}$ & 0.0953 & 0.1025 & 0.0463 & 0.0466 \\
\hline
\end{tabular}

Note: Z statistics are in parentheses; ${ }^{* * *},{ }^{* *},{ }^{*}$ Represent the significance at the level of 1,5 , $10 \%$ respectively.

required enterprises to pay more attention to energy conservation and environmental protection. Therefore, this study uses 2014 to divide the research sample. For the subsamples in different periods, this study still uses the empirical models constructed by Eq. 6 and Eq. 7, and the empirical results are reported in Table 6.

In Table 6, Columns (1) and (2) examine the impact of product market competition and industrial policy on the green innovation of sports goods manufacturing enterprises before 2014. In Column (1), the Policy coefficient is 1.3010, significant at the $1 \%$ level, while the association between product market competition and green innovation is not significant. In Column (2), interaction term coefficient (Competition * Policy) is -1.2986 , significant at the $1 \%$ level, and the coefficient of Competition is -2.3517 , significant at the $10 \%$ level, indicating that industrial policy can change the role of product market competition in promoting green innovation. Columns (3) and (4) explore the impact of product market competition and industrial policy on the green innovation of sports goods manufacturing enterprises after 2014. In Column (3), the Competition and Policy coefficients are 1.1378 and 0.0768 respectively, significant at the $1 \%$ level. In Column (4), the interaction term coefficient (Competition * Policy) is 0.0720 , significant at the $5 \%$ level, indicating that industrial policy can enhance the positive association between product market competition and green innovation. According to the empirical results in Table 6, under the loose environmental policy, industrial policy can aggravate the competition among sports goods manufacturing enterprises, which makes managers must abandon their investment in green innovation. However, under the strict environmental policy, managers need to rely on green innovation's outcomes to obtain competitive advantages. Besides, industrial policy can also increase their demands for green innovation.

\subsubsection{The Test of High-Polluting Industry}

For manufacturing enterprises, the degree of environmental degradation is usually determined by the type of manufacturing industry. The environmental degradation caused by non-high-polluting enterprises can be effectively controlled. High-polluting enterprises, however, require more resources and release more pollutants. For sports goods manufacturing enterprises, some enterprises may belong to high-polluting industries. In the Chinese market, highpolluting enterprises will face more constraints and restrictions from environmental policies, and suffer from higher penalties for environmental violations. Therefore, this study divides the research sample into the subsamples of non-high-polluting enterprises and the subsamples of high-polluting enterprises. This study still uses the empirical models constructed by Eq. 6 and Eq. 7, and the regression results are reported in Table 7.

In Table 7, Columns (1) and (2) examine the impact of product market competition and industrial policy on the green innovation of sports goods manufacturing enterprises in nohigh-polluting industries. In Column (1), Competition and Policy coefficients are 1.3621 and 1.4809 respectively, significant at the $1 \%$ level. In Column (2), the interaction term coefficient (Competition * Policy) is 0.0530 , but this is not significant. Columns (3) and (4) discuss the impact of product market competition and industrial policy on the green innovation of sports goods manufacturing enterprises in high-polluting industries. In Column (3), the Policy coefficient is 4.8833, significant at the $1 \%$ level, while the Competition coefficient is not significant. In Column (4), the interaction term coefficient (Competition * Policy) is not significant. According to the empirical results in Table 7 , industrial policy can significantly promote the green innovation of sports goods manufacturing enterprises in non-high-polluting and high-polluting industries, while product market competition can only promote the green innovation of non-high-polluting enterprises. The results of Columns (2) and (4) showed that the green innovation of high-polluting enterprises is only an approach to meet the regulatory requirements, and product market competition is hardly a motivation to promote green innovation in highpolluting enterprises.

\subsection{Further Test}

Previous studies on innovation found that, the relationship between product market competition and green innovation is likely to be non-linear. In this situation, the high level of product homogeneity may inhibit managers' motivation for 
TABLE 7 | Results of non-high-polluting and high-polluting industries.

\begin{tabular}{|c|c|c|c|c|}
\hline \multirow[t]{3}{*}{ Variables } & \multicolumn{4}{|c|}{ Green innovation } \\
\hline & \multicolumn{2}{|c|}{ Non-high-polluting enterprises } & \multicolumn{2}{|c|}{ High-polluting enterprises } \\
\hline & (1) & (2) & (3) & (4) \\
\hline Competition & $\begin{array}{c}1.3621^{\star \star \star} \\
(3.64)\end{array}$ & $\begin{array}{c}1.4129^{\star \star \star} \\
(3.72)\end{array}$ & $\begin{array}{c}0.2579 \\
(0.48)\end{array}$ & $\begin{array}{c}0.2880 \\
(0.51)\end{array}$ \\
\hline Policy & $\begin{array}{c}1.4809^{\star \star \star} \\
(2.59)\end{array}$ & $\begin{array}{c}1.5095^{\star \star \star *} \\
(2.68)\end{array}$ & $\begin{array}{c}4.8833^{\star \star \star} \\
(5.71)\end{array}$ & $\begin{array}{c}4.9083^{\star \star \star} \\
(5.59)\end{array}$ \\
\hline Competition * Policy & & $\begin{array}{c}0.0530 \\
(1.16)\end{array}$ & & $\begin{array}{c}0.0251 \\
(0.29)\end{array}$ \\
\hline $\mathrm{ROA}$ & $\begin{array}{c}7.7155^{\star \star \star} \\
(2.66)\end{array}$ & $\begin{array}{c}7.6814^{\star \star \star} \\
(2.65)\end{array}$ & $\begin{array}{c}-11.6836^{\star \star \star} \\
(-3.91)\end{array}$ & $\begin{array}{c}-11.6418^{\star \star \star} \\
(-3.91)\end{array}$ \\
\hline Liquidity & $\begin{array}{c}-1.7170^{\star \star} \\
(-2.13)\end{array}$ & $\begin{array}{c}-1.6774^{\star \star} \\
(-2.09)\end{array}$ & $\begin{array}{c}-0.0861 \\
(-0.09)\end{array}$ & $\begin{array}{c}-0.0770 \\
(-0.08)\end{array}$ \\
\hline Growth & $\begin{array}{c}-0.0901 \\
(-0.66)\end{array}$ & $\begin{array}{c}-0.0825 \\
(-0.60)\end{array}$ & $\begin{array}{c}0.1888 \\
(1.12)\end{array}$ & $\begin{array}{c}0.1904 \\
(1.13)\end{array}$ \\
\hline Return & $\begin{array}{c}0.2962 \\
(1.60)\end{array}$ & $\begin{array}{c}0.3023^{*} \\
(1.65)\end{array}$ & $\begin{array}{c}0.5766^{\star \star} \\
(2.09)\end{array}$ & $\begin{array}{c}0.5662^{*} \\
(1.95)\end{array}$ \\
\hline Subsidy & $\begin{array}{c}0.8707 \\
(0.22)\end{array}$ & $\begin{array}{c}1.7315 \\
(0.43)\end{array}$ & $\begin{array}{c}-53.4157^{\star} \\
(-1.90)\end{array}$ & $\begin{array}{c}-52.9712^{\star} \\
(-1.89)\end{array}$ \\
\hline Age & $\begin{array}{c}-0.3771 \\
(-1.06)\end{array}$ & $\begin{array}{l}-0.3677 \\
(-1.04)\end{array}$ & $\begin{array}{c}-1.0009^{\star \star} \\
(-2.15)\end{array}$ & $\begin{array}{c}-1.0103^{\star \star} \\
(-2.13)\end{array}$ \\
\hline Hold & $\begin{array}{c}-0.6823 \\
(-0.69)\end{array}$ & $\begin{array}{c}-0.7078 \\
(-0.71)\end{array}$ & $\begin{array}{c}2.6732^{\star \star \star} \\
(2.60)\end{array}$ & $\begin{array}{c}2.6717^{\star \star \star} \\
(2.61)\end{array}$ \\
\hline Independ & $\begin{array}{c}0.4458^{\star \star} \\
(2.42)\end{array}$ & $\begin{array}{c}0.4563^{\star \star} \\
(2.42)\end{array}$ & $\begin{array}{c}0.7209^{\star \star *} \\
(2.32)\end{array}$ & $\begin{array}{c}0.7178^{\star \star} \\
(2.33)\end{array}$ \\
\hline Constant & $\begin{array}{c}-2.4949 \\
(-1.55)\end{array}$ & $\begin{array}{c}-2.6365 \\
(-1.64)\end{array}$ & 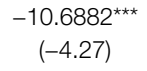 & $\begin{array}{c}-10.7178^{\star \star \star} \\
(-4.24)\end{array}$ \\
\hline Year & Yes & Yes & Yes & Yes \\
\hline Industry & Yes & Yes & Yes & Yes \\
\hline Observations & 1,208 & 1,208 & 911 & 911 \\
\hline Wald $\chi^{2}$ & 105.33 & 106.39 & 178.22 & 177.09 \\
\hline Pseudo $R^{2}$ & 0.0446 & 0.0447 & 0.0781 & 0.0782 \\
\hline
\end{tabular}

Note: $Z$ statistics are in parentheses; ${ }^{* *},{ }^{* *},{ }^{*}$ Represent the significance at the level of $1,5,10 \%$ respectively.

investment in green innovation. In addition, too many industrial policies may confuse the development strategy of enterprises, and even lead to market disruption. Therefore, this study constructs two new empirical models to explore the nonlinear impact of product market competition or industrial policy on the green innovation of sports goods manufacturing enterprises.

Green Innovation $_{i, t}=\alpha_{0}+\beta_{1}$ Competition $_{i, t-1}+\beta_{2}$ Competition $_{i, t-1}^{2}$ $+\beta_{3}$ ROA $_{i, t-1}+\beta_{4}$ Liquidit $_{i, t-1}+\beta_{5}$ Growth $_{i, t-1}$ $+\beta_{6}$ Return $_{i, t-1}+\beta_{7}$ Subsid $_{i, t-1}+\beta_{8}$ Age $_{i, t-1}$ $+\beta_{9}$ Hold $_{i, t-1}+\beta_{10}$ Independ $_{i, t-1}+$ Year $_{\text {fixed }}$ + Industr $y_{\text {fixed }}+\varepsilon$

Green Innovation ${ }_{i, t}=\alpha_{0}+\beta_{1}$ Polic $_{t-1}+\beta_{2}$ Polic $_{t-1}^{2}+\beta_{3} R O A_{i, t-1}$ $+\beta_{4}$ Liquidit $_{i, t-1}+\beta_{5}$ Growth $_{i, t-1}+\beta_{6}$ Return $_{i, t-1}$ $+\beta_{7}$ Subsid $_{i, t-1}+\beta_{8}$ Age $_{i, t-1}+\beta_{9}$ Hold $_{i, t-1}$ $+\beta_{10}$ Independ $_{i, t-1}+$ Year $_{\text {fixed }}+$ Industr $y_{\text {fixed }}+\varepsilon$

In Eq. 8 and Eq. 9, Competition ${ }_{i, t-1}^{2}$ and Policy $y_{t-1}^{2}$ are the squared term of product market competition and industrial policy. Based on the results of Table 5, financing constraints can play an important role in changing the impact of product market competition and industrial policy on green innovation. Therefore, this study still considers the subsamples with different financial constraints, and the regression results of nonlinear relationship are reported in Table $\mathbf{8}$.

In Table 8, Columns (1) and (2) examine the nonlinear relationship between product market competition or industrial policy and the green innovation of sports goods manufacturing enterprises in overall samples. In Column (1), there is no significant nonlinear relationship between product market competition and green innovation. In Column (2), the coefficient of Policy is 3.1753, significant at the $1 \%$ level, and the coefficient of Policy ${ }^{2}$ is -0.1983 , significant at the $1 \%$ level, which indicates that there is a significant inverted- $U$ shape relationship between industrial policy and green innovation, and this can support $\mathrm{H} 2 \mathrm{~b}$. With the appropriate number of industrial policies, green innovation in sports goods enterprises can be promoted, while an excessive number of industrial policies will inhibit green innovation outcomes. Columns (3) and (4) discuss the nonlinear relationship between product market competition or industrial policy and the green innovation of sports goods manufacturing enterprises with low financial constraints. In Column (3), the coefficient of 
TABLE 8 | Results of nonlinear relationship.

\begin{tabular}{|c|c|c|c|c|c|c|}
\hline \multirow[t]{3}{*}{ Variables } & \multicolumn{6}{|c|}{ Green innovation } \\
\hline & \multicolumn{2}{|c|}{ Overall samples } & \multicolumn{2}{|c|}{ Low constraints } & \multicolumn{2}{|c|}{ High constraints } \\
\hline & (1) & (2) & (3) & (4) & (5) & (6) \\
\hline Competition & $\begin{array}{c}-0.3907 \\
(-0.32)\end{array}$ & & $\begin{array}{c}-2.3930 * \\
(-1.68)\end{array}$ & & $\begin{array}{c}3.3729^{\star \star} \\
(2.48)\end{array}$ & \\
\hline Competition $^{2}$ & $\begin{array}{c}1.2557 \\
(1.29)\end{array}$ & & $\begin{array}{c}2.8926^{\star \star \star} \\
(2.66)\end{array}$ & & $\begin{array}{c}-3.2979^{\star \star \star} \\
(-2.96)\end{array}$ & \\
\hline Policy & & $\begin{array}{c}3.1753^{\star \star \star} \\
(5.66)\end{array}$ & & $\begin{array}{c}4.4731^{\star \star \star} \\
(6.69)\end{array}$ & & $\begin{array}{c}1.3892^{*} \\
(1.88)\end{array}$ \\
\hline Policy $^{2}$ & & $\begin{array}{c}-0.1983^{\star \star \star} \\
(-5.62)\end{array}$ & & $\begin{array}{c}-0.2798^{\star \star \star} \\
(-6.65)\end{array}$ & & $\begin{array}{c}-0.0865^{\star} \\
(-1.85)\end{array}$ \\
\hline $\mathrm{ROA}$ & $\begin{array}{c}-0.8807 \\
(-0.37)\end{array}$ & $\begin{array}{c}0.5351 \\
(0.21)\end{array}$ & $\begin{array}{c}-0.6991 \\
(-0.21)\end{array}$ & $\begin{array}{c}0.9431 \\
(0.26)\end{array}$ & $\begin{array}{c}-1.3008 \\
(-0.61)\end{array}$ & $\begin{array}{c}-2.0779 \\
(-0.92)\end{array}$ \\
\hline Liquidity & $\begin{array}{c}-1.2049^{\star} \\
(-1.75)\end{array}$ & $\begin{array}{c}-1.1670 \\
(-1.59)\end{array}$ & $\begin{array}{c}-1.0690 \\
(-1.44)\end{array}$ & $\begin{array}{c}-0.9749 \\
(-1.21)\end{array}$ & $\begin{array}{c}-0.7803 \\
(-0.93)\end{array}$ & $\begin{array}{c}-0.6500 \\
(-0.79)\end{array}$ \\
\hline Growth & $\begin{array}{c}-0.0137 \\
(-0.11)\end{array}$ & $\begin{array}{c}-0.0240 \\
(-0.18)\end{array}$ & $\begin{array}{c}-0.1100 \\
(-0.67)\end{array}$ & $\begin{array}{c}-0.0935 \\
(-0.53)\end{array}$ & $\begin{array}{c}0.2086 \\
(0.70)\end{array}$ & $\begin{array}{c}0.2999 \\
(0.97)\end{array}$ \\
\hline Return & $\begin{array}{c}0.4577^{\star \star \star} \\
(2.88)\end{array}$ & $\begin{array}{c}0.4928^{\star \star \star} \\
(3.12)\end{array}$ & $\begin{array}{c}0.5435^{\star \star} \\
(2.36)\end{array}$ & $\begin{array}{c}0.5643^{\star \star} \\
(2.46)\end{array}$ & $\begin{array}{c}0.3320 \\
(1.43)\end{array}$ & $\begin{array}{c}0.3073 \\
(1.25)\end{array}$ \\
\hline Subsidy & $\begin{array}{c}1.3006 \\
(0.34)\end{array}$ & $\begin{array}{c}3.0279 \\
(0.32)\end{array}$ & $\begin{array}{c}12.0046 \\
(0.65)\end{array}$ & $\begin{array}{c}27.3418 \\
(1.37)\end{array}$ & $\begin{array}{c}0.2693 \\
(0.10)\end{array}$ & $\begin{array}{c}0.9952 \\
(0.37)\end{array}$ \\
\hline Age & $\begin{array}{c}--0.6533^{\star \star} \\
(-2.02)\end{array}$ & $\begin{array}{c}-0.6218^{\star} \\
(-1.83)\end{array}$ & $\begin{array}{c}-0.4590 \\
(-1.31)\end{array}$ & $\begin{array}{c}-0.5014 \\
(-1.43)\end{array}$ & $\begin{array}{c}-1.0398^{\star \star \star} \\
(-2.99)\end{array}$ & $\begin{array}{c}-0.9500^{\star \star *} \\
(-2.61)\end{array}$ \\
\hline Hold & $\begin{array}{c}0.2390 \\
(0.30)\end{array}$ & $\begin{array}{c}0.0234 \\
(0.03)\end{array}$ & $\begin{array}{c}-0.1064 \\
(-0.12)\end{array}$ & $\begin{array}{c}-0.3207 \\
(-0.39)\end{array}$ & $\begin{array}{c}-0.9912 \\
(-0.94)\end{array}$ & $\begin{array}{c}-0.8159 \\
(-0.76)\end{array}$ \\
\hline Independ & $\begin{array}{c}0.4240^{\star \star \star} \\
(2.27)\end{array}$ & $\begin{array}{c}0.3866^{\star \star} \\
(2.02)\end{array}$ & $\begin{array}{c}0.3738^{\star \star} \\
(2.14)\end{array}$ & $\begin{array}{c}0.2897 \\
(1.63)\end{array}$ & $\begin{array}{c}-0.1789 \\
(-0.68)\end{array}$ & $\begin{array}{c}-0.1260 \\
(-0.47)\end{array}$ \\
\hline Constant & $\begin{array}{c}-1.1809 \\
(-0.84)\end{array}$ & $\begin{array}{c}-3.6346^{\star \star} \\
(-2.43)\end{array}$ & $\begin{array}{c}-1.6231 \\
(-1.12)\end{array}$ & $\begin{array}{c}-5.3661^{\star \star \star} \\
(-3.26)\end{array}$ & $\begin{array}{c}1.2241 \\
(0.78)\end{array}$ & $\begin{array}{c}0.0350 \\
(0.02)\end{array}$ \\
\hline Year & Yes & Yes & Yes & Yes & Yes & Yes \\
\hline Industry & Yes & Yes & Yes & Yes & Yes & Yes \\
\hline Observations & 2,119 & 2,119 & 1,062 & 1,062 & 1,057 & 1,057 \\
\hline Wald $\chi^{2}$ & 193.55 & 183.71 & 209.65 & 193.15 & 215.44 & 259.46 \\
\hline Pseudo $R^{2}$ & 0.0572 & 0.0531 & 0.0638 & 0.0582 & 0.0769 & 0.0715 \\
\hline
\end{tabular}

Note: $Z$ statistics are in parentheses; ${ }^{* * *},{ }^{* *}$, ${ }^{*}$ Represent the significance at the level of $1,5,10 \%$ respectively.

Competition is -2.3930 , significant at the $10 \%$ level, and the coefficient of Competition ${ }^{2}$ is 2.8926 , significant at the $1 \%$ level, which indicates that there is a significant $U$ shape relationship between product market competition and green innovation, and this can support H1b. In Column (4), there is a significant inverted-U shape relationship between industrial policy and green innovation. Columns (5) and (6) discuss the nonlinear relationship between product market competition or industrial policy and the green innovation of sports goods manufacturing enterprises with high financial constraints. In Column (5), the coefficient of Competition is 3.3729, significant at the $5 \%$ level, and the coefficient of Competition ${ }^{2}$ is -3.2979 , significant at the $1 \%$ level, which indicates that there is a significant inverted-U shape relationship between product market competition and green innovation, and this can support H1b. In Column (6), there is still a significant inverted-U shape relationship between industrial policy and green innovation. According to the empirical results in Table 8, there is always an inverted-U shape relationship between industrial policy and green innovation. This indicates that the benefits of industrial policy can alleviate the financial constraints faced by sports goods manufacturing enterprises and thus facilitate their green innovation outcomes. As the number of industrial policies increases, sports goods manufacturing enterprises may use government subsidies for other businesses, resulting in less investment in green innovation. Moreover, the growth of financial constraints will change the nonlinear relationship between product market competition and green innovation. In this situation, high financial constraints may reduce managers' attention to the environmental benefits of green innovation, thus driving them to focus more on short-term profits.

\subsection{Robustness Test}

In our research setting, the empirical models constructed in Section 4.3 may be influenced by the endogeneity of some variables. Although the independent variables and the control variables lag 1 year respectively, this may not be sufficient to resolve the problems of endogeneity. Refer to Wang and Hagedoorn (2014), this study reports robustness checks with longer lags (Wang and Hagedoorn, 2014). Independent variables and control variables are treated within a potential number of lags equal to s. Therefore, the new empirical models are constructed as follow: 
TABLE 9 | Results of robustness checks.

\begin{tabular}{|c|c|c|c|c|c|c|c|c|c|c|}
\hline \multirow[t]{3}{*}{ Variables } & \multicolumn{10}{|c|}{ Green innovation } \\
\hline & \multicolumn{2}{|c|}{$\mathbf{s}=0$} & \multicolumn{2}{|c|}{$s=2$} & \multicolumn{2}{|c|}{$\mathbf{s}=3$} & \multicolumn{2}{|c|}{$s=4$} & \multicolumn{2}{|c|}{$s=5$} \\
\hline & (1) & (2) & (3) & (4) & (5) & (6) & (7) & (8) & (9) & (10) \\
\hline Competition $_{t-s}$ & $\begin{array}{c}0.3478^{\star} \\
(1.73)\end{array}$ & $\begin{array}{c}0.3434^{\star} \\
(1.74)\end{array}$ & $\begin{array}{c}0.5344^{\star} \\
(1.92)\end{array}$ & $\begin{array}{c}0.5310^{*} \\
(1.94)\end{array}$ & $\begin{array}{c}0.1903 \\
(0.68)\end{array}$ & $\begin{array}{c}-2.0958^{\star \star} \\
(-2.27)\end{array}$ & $\begin{array}{c}0.0578 \\
(0.16)\end{array}$ & $\begin{array}{c}-0.4580 \\
(-0.48)\end{array}$ & $\begin{array}{c}0.4287 \\
(1.05)\end{array}$ & $\begin{array}{c}-0.8419 \\
(-0.80)\end{array}$ \\
\hline Policy $_{t-s}$ & $\begin{array}{c}0.3426^{\star \star \star} \\
(4.46)\end{array}$ & $\begin{array}{c}0.3399^{\star \star \star} \\
(4.47)\end{array}$ & $\begin{array}{c}0.2026^{\star \star \star} \\
(5.61)\end{array}$ & $\begin{array}{c}0.2028^{\star \star \star} \\
(5.60)\end{array}$ & $\begin{array}{c}-1.5257^{\text {*** }} \\
(-3.84)\end{array}$ & $\begin{array}{c}-1.4995^{\star \star \star} \\
(-3.85)\end{array}$ & $\begin{array}{c}0.7495 \\
(1.28)\end{array}$ & $\begin{array}{c}0.7254 \\
(1.25)\end{array}$ & $\begin{array}{c}0.8248 \\
(1.49)\end{array}$ & $\begin{array}{c}0.7916 \\
(1.47)\end{array}$ \\
\hline Competition $*$ Policy $_{t-s}$ & & $\begin{array}{c}0.0445 \\
(0.92)\end{array}$ & & $\begin{array}{c}0.0035^{\star} \\
(1.97)\end{array}$ & & $\begin{array}{c}-0.8709^{\star \star \star} \\
(-2.68)\end{array}$ & & $\begin{array}{c}-0.2422 \\
(-0.62)\end{array}$ & & $\begin{array}{c}-0.5849 \\
(-1.51)\end{array}$ \\
\hline$R O A_{t-s}$ & $\begin{array}{c}1.0224 \\
(0.96)\end{array}$ & $\begin{array}{c}1.0304 \\
(0.97)\end{array}$ & $\begin{array}{c}2.7606 \\
(1.37)\end{array}$ & $\begin{array}{c}2.7548 \\
(1.37)\end{array}$ & $\begin{array}{c}0.4067 \\
(0.20)\end{array}$ & $\begin{array}{c}1.5916 \\
(0.81)\end{array}$ & $\begin{array}{c}2.3447 \\
(0.76)\end{array}$ & $\begin{array}{c}2.4781 \\
(0.80)\end{array}$ & $\begin{array}{c}-3.0631 \\
(-0.75)\end{array}$ & $\begin{array}{c}-2.5814 \\
(-0.65)\end{array}$ \\
\hline Liquidityt-s $_{t}$ & $\begin{array}{c}-0.8109^{\star *} \\
(-2.29)\end{array}$ & $\begin{array}{c}-0.8445^{\star \star} \\
(-2.40)\end{array}$ & $\begin{array}{c}-0.6675 \\
(-1.15)\end{array}$ & $\begin{array}{c}-0.6606 \\
(-1.10)\end{array}$ & $\begin{array}{c}-1.5708^{\star \star} \\
(-2.41)\end{array}$ & $\begin{array}{c}-1.9022^{\star \star \star} \\
(-2.93)\end{array}$ & $\begin{array}{c}-2.3322^{\star \star \star} \\
(-2.26)\end{array}$ & $\begin{array}{c}-2.4261^{\star \star \star} \\
(-2.74)\end{array}$ & $\begin{array}{c}-1.6690^{\star \star} \\
(-2.11)\end{array}$ & $\begin{array}{c}-1.7951^{\text {** }} \\
(-2.21)\end{array}$ \\
\hline Growth $_{t-s}$ & $\begin{array}{c}-0.0699 \\
(-0.72)\end{array}$ & $\begin{array}{c}-0.0711 \\
(-0.73)\end{array}$ & $\begin{array}{c}-0.1839 \\
(-1.22)\end{array}$ & $\begin{array}{c}-0.1837 \\
(-1.21)\end{array}$ & $\begin{array}{c}0.2946 \\
(1.20)\end{array}$ & $\begin{array}{c}0.4204 \\
(1.61)\end{array}$ & $\begin{array}{c}-0.0787 \\
(-0.32)\end{array}$ & $\begin{array}{c}-0.0546 \\
(-0.22)\end{array}$ & $\begin{array}{c}0.0490 \\
(0.23)\end{array}$ & $\begin{array}{c}0.0282 \\
(0.13)\end{array}$ \\
\hline Return $_{t-s}$ & $\begin{array}{c}0.0185 \\
(0.12)\end{array}$ & $\begin{array}{c}0.0242 \\
(0.15)\end{array}$ & $\begin{array}{l}-0.0167 \\
(-0.08)\end{array}$ & $\begin{array}{c}-0.0169 \\
(-0.08)\end{array}$ & $\begin{array}{c}0.0406 \\
(0.19)\end{array}$ & $\begin{array}{c}0.0997 \\
(0.46)\end{array}$ & $\begin{array}{l}-0.0761 \\
(-0.28)\end{array}$ & $\begin{array}{l}-0.0337 \\
(-0.12)\end{array}$ & $\begin{array}{c}0.4154 \\
(1.19)\end{array}$ & $\begin{array}{c}0.4479 \\
(1.27)\end{array}$ \\
\hline Subsidyt-s & $\begin{array}{c}-1.4010 \\
(-0.66)\end{array}$ & $\begin{array}{c}-1.6921 \\
(-0.75)\end{array}$ & $\begin{array}{c}3.9673 \\
(0.47)\end{array}$ & $\begin{array}{c}3.9933 \\
(0.48)\end{array}$ & $\begin{array}{c}-1.1366 \\
(-0.08)\end{array}$ & $\begin{array}{c}-5.0062 \\
(-0.35)\end{array}$ & $\begin{array}{c}-1.2436 \\
(-0.11)\end{array}$ & $\begin{array}{c}-1.6580 \\
(-0.15)\end{array}$ & $\begin{array}{c}-4.7104 \\
(-0.17)\end{array}$ & $\begin{array}{c}-6.8231 \\
(-0.24)\end{array}$ \\
\hline$A g \mathrm{e}_{t-s}$ & $\begin{array}{c}-0.4581^{\star \star \star} \\
(-2.74)\end{array}$ & $\begin{array}{c}-0.4597^{\star \star \star} \\
(-2.75)\end{array}$ & $\begin{array}{c}-0.7056^{\star \star \star} \\
(-2.98)\end{array}$ & $\begin{array}{c}-0.7061^{\star \star \star} \\
(-2.99)\end{array}$ & $\begin{array}{c}-0.4549^{\star \star} \\
(-1.96)\end{array}$ & $\begin{array}{c}-0.5013^{\star \star} \\
(-2.13)\end{array}$ & $\begin{array}{c}-0.7384^{\star \star \star} \\
(-3.18)\end{array}$ & $\begin{array}{c}-0.7372^{\star \star \star} \\
(-3.18)\end{array}$ & $\begin{array}{c}-0.7474^{\star \star \star} \\
(-2.79)\end{array}$ & $\begin{array}{c}-0.7070^{\star \star \star} \\
(-2.62)\end{array}$ \\
\hline $\mathrm{Hold}_{t-s}$ & $\begin{array}{c}0.0123 \\
(0.03)\end{array}$ & $\begin{array}{c}0.0302 \\
(0.07)\end{array}$ & $\begin{array}{c}0.3404 \\
(0.45)\end{array}$ & $\begin{array}{c}0.3335 \\
(0.45)\end{array}$ & $\begin{array}{c}0.9845 \\
(1.30)\end{array}$ & $\begin{array}{c}1.0361 \\
(1.32)\end{array}$ & $\begin{array}{c}1.9627^{\star *} \\
(2.34)\end{array}$ & $\begin{array}{c}1.9489^{\star \star} \\
(2.32)\end{array}$ & $\begin{array}{c}2.5520^{\star \star \star} \\
(2.79)\end{array}$ & $\begin{array}{c}2.6720^{\star \star \star} \\
(2.88)\end{array}$ \\
\hline Independ $_{t-s}$ & $\begin{array}{c}0.5165^{\star \star \star} \\
(6.00)\end{array}$ & $\begin{array}{c}0.5166^{\star \star \star} \\
(5.97)\end{array}$ & $\begin{array}{c}0.4718^{\star \star \star} \\
(3.64)\end{array}$ & 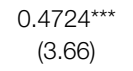 & $\begin{array}{c}0.2549 \\
(1.51)\end{array}$ & $\begin{array}{c}0.2558 \\
(1.53)\end{array}$ & $\begin{array}{c}-0.0793 \\
(-0.51)\end{array}$ & $\begin{array}{c}-0.0774 \\
(-0.50)\end{array}$ & $\begin{array}{c}-0.1181 \\
(-0.74)\end{array}$ & $\begin{array}{c}-0.1351 \\
(-0.88)\end{array}$ \\
\hline Constant & $\begin{array}{c}-1.1364 \\
(-1.61)\end{array}$ & $\begin{array}{c}-1.1075 \\
(-1.57)\end{array}$ & $\begin{array}{c}-1.8649^{\star} \\
(-1.82)\end{array}$ & $\begin{array}{c}-1.8646^{\star} \\
(-1.82)\end{array}$ & $\begin{array}{c}1.5500 \\
(1.41)\end{array}$ & $\begin{array}{c}3.3098^{\star \star} \\
(2.51)\end{array}$ & $\begin{array}{c}0.9419 \\
(0.61)\end{array}$ & $\begin{array}{c}1.3607 \\
(0.77)\end{array}$ & $\begin{array}{c}-0.0453 \\
(-0.03)\end{array}$ & $\begin{array}{c}0.8184 \\
(0.52)\end{array}$ \\
\hline Year & Yes & Yes & Yes & Yes & Yes & Yes & Yes & Yes & Yes & Yes \\
\hline Industry & Yes & Yes & Yes & Yes & Yes & Yes & Yes & Yes & Yes & Yes \\
\hline Observations & 2,119 & 2,119 & 2,119 & 2,119 & 2,119 & 2,119 & 2,119 & 2,119 & 2,119 & 2,119 \\
\hline Wald $\chi^{2}$ & 514.26 & 509.40 & 275.12 & 277.86 & 174.74 & 192.07 & 167.63 & 164.22 & $1,415.86$ & $1,350.92$ \\
\hline Pseudo $R^{2}$ & 0.0561 & 0.0563 & 0.0693 & 0.0693 & 0.0588 & 0.0615 & 0.0776 & 0.0777 & 0.0820 & 0.0836 \\
\hline
\end{tabular}

Note: $Z$ statistics are in parentheses; ${ }^{* * *},{ }^{* *},{ }^{*}$ Represent the significance at the level of $1,5,10 \%$ respectively.

Green Innovation $_{i, t}=\alpha_{0}+\beta_{1}$ Competition $_{i, t-s}+\beta_{2}$ Polic $_{t-s}$ $+\beta_{3} R O A_{i, t-s}+\beta_{4}$ Liquidity $_{i, t-s}+\beta_{5}$ Growth $_{i, t-s}$ $+\beta_{6}$ Return $_{i, t-s}+\beta_{7}$ Subsid $y_{i, t-s}+\beta_{8}$ Age $_{i, t-s}$ $+\beta_{9}$ Hold $_{i, t-s}+\beta_{10}$ Independ $_{i, t-s}+$ Year $_{\text {fixed }}$ + Industry $y_{\text {fixed }}+\varepsilon$

Green Innovation $_{i, t}=\alpha_{0}+\beta_{1}$ Competition $_{i, t-s}+\beta_{2}$ Polic $_{t-s}$ $+\beta_{3}$ Competition $_{i, t-s} \times$ Polic $_{t-s}+\beta_{4} R O A_{i, t-s}$ $+\beta_{5}$ Liquidit $_{i, t-s}+\beta_{6}$ Growth $_{i, t-s}$ $+\beta_{7}$ Return $_{i, t-s}+\beta_{8}$ Subsid $_{i, t-s}+\beta_{9}$ Age $_{i, t-s}$ $+\beta_{10}$ Hold $_{i, t-s}+\beta_{11}$ Independ $_{i, t-s}+$ Year $_{\text {fixed }}$ + Industry $_{\text {fixed }}+\varepsilon$

In Eq. 10 and Eq. 11, the definitions of variables are provided in Table 1. $s$ stands for lag structure. Refer to the method mentioned in previous studies, $s$ is set to 0 to test the contemporaneous effect of independent and control variables (Fabrizi et al., 2018); (Costantini et al., 2015). Moreover, this study tests the lag effect of such variables for $s$ assuming value 1,2, 3, 4, and 5. The robustness results are reported in Table 9.
In Table 9, Columns (1) and (2) examine the impact of product market competition and industrial policy on green innovation in the same period. It can be found that there is strong contemporaneous effect of product market competition and industrial policy, with significant positive coefficients in year t. In addition, Columns (3)-(10) explore the impact of product market competition and industrial policy on green innovation during the longer lags period. There is still strong lag effect of product market competition, with significant positive coefficient in year $\mathrm{t}-2$. However, a negative and significant effect of industrial policy is found in year $t-3$, and it can also change the association between product market competition and green innovation. Industrial policy can only provide motivations to sports goods manufacturing enterprises within one to 2 year. After 3 years, industrial policy may become an uncertain factor, which will affect the decision-making of managers in R\&D activities, especially in green innovation. In year $\mathrm{t}-4$ and year $\mathrm{t}-5$, there is no significant lag effect of product market competition and industrial policy. These findings can support the robustness of empirical results obtained from the basic models. 


\section{DISCUSSION}

The investment of sports goods manufacturing enterprises in green innovation will be represented through green technological innovation, i.e., energy conservation and environmental protection. In the Chinese market, sports goods manufacturing enterprises are smaller than other manufacturing enterprises, which also makes their $\mathrm{R} \& \mathrm{D}$ activities to be limited by the shortage of funds. It is worth noting that sports goods manufacturing enterprises have developed numerous green innovation outcomes, indicating that such enterprises need to obtain environmental benefits through green innovation (Chen et al., 2020). In this situation, external factors play an important role in driving the green innovation activities of sports goods manufacturing enterprises. Sports goods manufacturing enterprises need to use green innovation to obtain unique competitive advantages to alleviate market share pressure. Furthermore, industrial policy reflects the government's willingness to upgrade the industrial structure of the sports goods manufacturing industry, forcing such enterprises to invest more resources in green innovation. From these two external factors, the demand of sports goods manufacturing enterprises for green innovation will increase, and managers need to rely on green innovation outcomes to obtain environmental benefits, to get investors' attention and meet the government's requirements (Chen, 2008).

According to the empirical results in Section 5, product market competition and industrial policy can significantly promote the green innovation of sports goods manufacturing enterprises. Although these findings differ from Schumpeter's innovation theory, this paper further demonstrates that industrial policy can moderate the role of product market competition in promoting green innovation. According to the baseline test and heterogeneity test, the industrial policy will create the highly competitive environment faced by sports goods manufacturing enterprises, thus forcing sports goods manufacturing enterprises to use green innovation to eliminate this dilemma (Zhao et al., 2018). Similar to the findings of Aghion et al. (2005) (Aghion et al., 2005), this study finds from the results of non-linear relationship a significant inverted-U shape relationship between product market competition and green innovation under the condition of high financial constraints, which is also similar to the findings of Aghion et al. (2005) (Aghion et al., 2005). Notably, the growth of financial constraints can alter the nonlinear relationship between product market competition and green innovation, suggesting that high financial constraints can reduce the demand of sports goods manufacturing enterprises for green innovation. Moreover, the promotion of product market competition may mainly exist in sports goods manufacturing enterprises with low financial constraints. In terms of industrial policy, the findings of this study demonstrate the important role of government factors in green innovation. The investment of sports goods manufacturing enterprises in green innovation is used to obtain the benefits of industrial policy and meet the requirements of government, which also supports the findings of Im et al. (2015). This study explains the impact of competition environment and macro policy on green innovation, and demonstrates the driving role of external factors in $R \& D$ activities.

\section{CONCLUSION AND RECOMMENDATIONS}

\subsection{Conclusion}

Green innovation is pivotal for balancing economic profitability and environmental protection. The driving factors of green innovation mainly come from two dimensions, i.e., organizational factors and external factors. First, enterprises rely on green innovation outcomes to obtain environmental benefits to achieve competitive advantages. Second, the pressure from competitive environment and government forces enterprises to invest more in green innovation to relieve the market share pressure and support the sustainable development of the regional economy. This study focuses on the driving factors of green innovation of sports goods manufacturing enterprises in the Chinese market. China's sports goods manufacturing enterprises are smaller than other manufacturing enterprises, as well as their profitability. These internal limitations have become the main obstacles of green innovation activities.

To better explain the efforts of sports goods manufacturing enterprises in green innovation, this study discusses the impact of product market competition and industrial policy on green innovation. Unlike the previous studies on product market competition, this study utilizes the method of textual analysis to identify sports goods manufacturing enterprises and measures the degree of competition faced by each sports goods manufacturing enterprise. Furthermore, the intensity of policy of sports-related industries is obtained by a manual way, which can show the impact of industrial policy on green innovation at the macro level. It is interesting that product market competition and industrial policy can promote green innovation, and industrial policy can also moderate this relationship. Considering the characteristics of China's manufacturing industries, the implementation of industrial policy may intensify the competition among enterprises, forcing enterprises to obtain competitive advantages through innovation outcomes. These findings are verified from different dimensions, including financial constraints, environmental policy and high-polluting industries.

This study also demonstrates that there is an inverted- $U$ shape relationship between industrial policy and green innovation. The benefits of industrial policy can reduce the financial pressure of enterprises, and motivate managers to invest in. However, excessive industrial policies will make managers use government subsidies for other businesses, thus reducing the investment in green innovation. Interestingly, the growth of financial constraints can change the nonlinear relationship between product market competition and green innovation, and managers faced with high financial constraints will ignore the environmental benefits of green innovation.

Green innovation is an essential approach for sports goods manufacturing enterprises to achieve the equilibrium between 
environmental performance and economic profitability. This study explores the driving factors of green innovation of sporting goods manufacturing enterprises and also discusses the moderating role of government factor on market factor. Consistent with the theory of corporate innovation, this study explains the efforts of sports goods manufacturing enterprises in green innovation from two dimensions, namely product market competition and industrial policy. The findings of this study can help sports goods manufacturing enterprises to make a rational resource allocation, and design some sustainable development strategies.

\subsection{Recommendations and Limitations}

This study identifies China's sports goods manufacturing enterprises from a new perspective and analyzes the driving factors of green innovation of such enterprises. Under different financial constraints, this study discusses the relationship between product market competition and green innovation, and explains why competition can inhibit the investment of enterprises in green innovation. According to the theoretical analysis and empirical analysis, this study has some implications as follows:

Firstly, the managers of sports goods manufacturing enterprises need to understand the relationship between product market competition and sustainable development. In Chinese market, the internal resources of sports goods manufacturing enterprises are often intricate to effectively support their green innovation activities. Faced with the highly competitive environment, sports goods manufacturing enterprises need to use green innovation outcomes to balance between environmental performance and economic profitability. Green innovation can not only improve the production of sports goods manufacturing enterprises, but also provide unique competitive advantages for such enterprises. Understanding the importance of sustainable development will help such enterprises alleviate the pressure of market share.

Secondly, sports goods manufacturing enterprises need to rationally design the strategies of green innovation according to industrial policies. Although the industrial policy can promote the green innovation of the sports goods manufacturing enterprises, excessive policies may also enhance the intensity of competition among enterprises.

\section{REFERENCES}

Aghion, P., Bloom, N., Blundell, R., Griffith, R., and Howitt, P. (2005). Competition and Innovation: An Inverted-U Relationship*. Q. J. Econ. 120, 701-728. doi:10.1093/qje/120.2.70110.1162/0033553053970214

Aghion, P., Howitt, P., and Prantl, S. (2015). Patent Rights, Product Market Reforms, and Innovation. J. Econ. Growth 20, 223-262. doi:10.1007/s10887015-9114-3

Amore, M. D., and Bennedsen, M. (2016). Corporate Governance and green Innovation. J. Environ. Econ. Manag. 75, 54-72. doi:10.1016/j.jeem.2015.11.003

Ayyagari, M., Demirgüç-Kunt, A., and Maksimovic, V. (2011). Firm Innovation in Emerging Markets: The Role of Finance, Governance, and Competition. J. Financ. Quant. Anal. 46, 1545-1580. doi:10.1017/ S0022109011000378
However, sports goods manufacturing enterprises need to pay more attention to consumer demand and adjust their green innovation strategies suited to the domestic and foreign markets. As industrial policies will upgrade the industrial structure of the sports goods manufacturing industry, such enterprises need to predict the trend of industrial development, to maintain their position in the product market.

There are some limitations to this study. In terms of text data, this study uses the annual reports of China's A-share listed companies as the main source of sporting goods words, but this method may ignore some sports goods involved in the Chinese market. This text data limitation may restrict the process of constructing the competitive environment faced by each enterprise. In addition, this study does not consider the unlisted sports goods manufacturing enterprises, rendering the research sample unrepresentative of sports goods market.

\section{DATA AVAILABILITY STATEMENT}

The original contributions presented in the study are included in the article/Supplementary Material, further inquiries can be directed to the corresponding author.

\section{AUTHOR CONTRIBUTIONS}

$\mathrm{CH}$ : conceptualization, methodology, software, investigation, writing-original draft, writing-review and editing, visualization, supervision, project administration, and funding acquisition. YC: methodology, validation, formal analysis, data curation, writing-review and editing, and visualization. All authors contributed to the article and approved the submitted version.

\section{SUPPLEMENTARY MATERIAL}

The Supplementary Material for this article can be found online at: https:/www.frontiersin.org/articles/10.3389/fenvs.2021.809156/ full\#supplementary-material

Bergek, A., and Berggren, C. (2014). The Impact of Environmental Policy Instruments on Innovation: A Review of Energy and Automotive Industry Studies. Ecol. Econ. 106, 112-123. doi:10.1016/ j.ecolecon.2014.07.016

Bhattacharya, U., Hsu, P.-H., Tian, X., and Xu, Y. (2017). What Affects Innovation More: Policy or Policy Uncertainty? J. Financ. Quant. Anal. 52, 1869-1901. doi:10.1017/S0022109017000540

Bonfatti, R., and Pisano, L. (2020). Credit Constraints and the Inverted-U Relationship between Competition and Innovation. Economica 87, 442-469. doi:10.1111/ecca.12312

Brodzicki, T. (2019). The Intensity of Market Competition and the Innovative Performance of Firms. Innovation 21, 336-358. doi:10.1080/14479338.2018.1532296

Brunel, C. (2019). Green Innovation and green Imports:Links between Environmental Policies, Innovation, and Production. J. Environ. Manage. 248, 109290. doi:10.1016/j.jenvman.2019.109290 
Cao, S., Feng, F., Chen, W., and Zhou, C. (2020). Does Market Competition Promote Innovation Efficiency in China's High-Tech Industries? Tech. Anal. Strateg. Manag. 32, 429-442. doi:10.1080/09537325.2019.1667971

Castellacci, F., and Lie, C. M. (2017). A Taxonomy of green Innovators: Empirical Evidence from South Korea. J. Clean. Prod. 143, 1036-1047. doi:10.1016/ j.jclepro.2016.12.016

Chang, C.-H. (2019). Do green Motives Influence green Product Innovation? the Mediating Role of green Value Co-creation. Corp Soc. Resp Env Ma 26, 330-340. doi:10.1002/csr.1685

Chang, C.-H. (2018). How to Enhance Green Service and Green Product Innovation Performance? the Roles of Inward and Outward Capabilities. Corp. Soc. Responsib. Environ. Mgmt. 25, 411-425. doi:10.1002/csr.1469

Chen, G., Mao, L. L., Pifer, N. D., and Zhang, J. J. (2020). Innovation-driven Development Strategy and Research Development Investment: a Case Study of Chinese Sport Firms. Apjml 33, 1578-1595. doi:10.1108/APJML03-2020-0181

Chen, Y.-S. (2008). The Driver of green Innovation and green Image - Green Core Competence. J. Bus Ethics 81, 531-543. doi:10.1007/s10551-0079522-1

Cheng, J., and Liu, Y. (2018). The Effects of Public Attention on the Environmental Performance of High-Polluting Firms: Based on Big Data from Web Search in China. J. Clean. Prod. 186, 335-341. doi:10.1016/j.jclepro.2018.03.146

Chu, Z., Wang, L., and Lai, F. (2019). Customer Pressure and green Innovations at Third Party Logistics Providers in China. Ijlm 30, 57-75. doi:10.1108/IJLM-112017-0294

Costantini, V., Crespi, F., Martini, C., and Pennacchio, L. (2015). Demand-pull and Technology-Push Public Support for Eco-Innovation: The Case of the Biofuels Sector. Res. Pol. 44, 577-595. doi:10.1016/j.respol.2014.12.011

Crowley, F., and Jordan, D. (2017). Does More Competition Increase BusinessLevel Innovation? Evidence from Domestically Focused Firms in Emerging Economies. Econ. Innovation New Tech. 26, 477-488. doi:10.1080/ 10438599.2016.1233627

Damanpour, F. (2010). An Integration of Research Findings of Effects of Firm Size and Market Competition on Product and Process Innovations. Br. J. Manag. 21, 996-1010. doi:10.1111/j.1467-8551.2009.00628.x

Fabrizi, A., Guarini, G., and Meliciani, V. (2018). Green Patents, Regulatory Policies and Research Network Policies. Res. Pol. 47, 1018-1031. doi:10.1016/j.respol.2018.03.005

Feng, F. (2019). Does Industrial Policy Play an Important Role in Enterprise Innovation? Emerging Markets Finance and Trade 55, 3490-3512. doi:10.1080/ 1540496X.2019.1649654

Griffith, R., Harrison, R., and Simpson, H. (2010). Product Market Reform and Innovation in the EU*. Scand. J. Econ. 112, 389-415. doi:10.1111/j.14679442.2010.01602.x

Hadlock, C. J., and Pierce, J. R. (2010). New Evidence on Measuring Financial Constraints: Moving beyond the KZ index. Rev. Financ. Stud. 23, 1909-1940. doi:10.1093/rfs/hhq009

Hoberg, G., and Phillips, G. (2016). Text-Based Network Industries and Endogenous Product Differentiation. J. Polit. Economy 124, 1423-1465. doi:10.1086/688176

Huang, J.-W., and Li, Y.-H. (2017). Green Innovation and Performance: The View of Organizational Capability and Social Reciprocity. J. Bus Ethics 145, 309-324. doi:10.1007/s10551-015-2903-y

Huang, Z., Liao, G., and Li, Z. (2019). Loaning Scale and Government Subsidy for Promoting green Innovation. Technol. Forecast. Soc. Change 144, 148-156. doi:10.1016/j.techfore.2019.04.023

Im, H. J., Park, Y. J., and Shon, J. (2015). Product Market Competition and the Value of Innovation: Evidence from US Patent Data. Econ. Lett. 137, 78-82. doi:10.1016/j.econlet.2015.10.017

Jiang, Z., Wang, Z., and Li, Z. (2018). The Effect of Mandatory Environmental Regulation on Innovation Performance: Evidence from China. J. Clean. Prod. 203, 482-491. doi:10.1016/j.jclepro.2018.08.078

Jun, W., Ali, W., Bhutto, M. Y., Hussain, H., and Khan, N. A. (2019). Examining the Determinants of green Innovation Adoption in SMEs: a PLS-SEM Approach. Ejim 24, 67-87. doi:10.1108/EJIM-05-2019-0113

Karimi Takalo, S., Sayyadi Tooranloo, H., and Shahabaldini parizi, Z. (2021). Green Innovation: A Systematic Literature Review. J. Clean. Prod. 279, 122474. doi:10.1016/j.jclepro.2020.122474
Katselas, D., Sidhu, B. K., and Yu, C. (2019). Know Your Industry: the Implications of Using Static GICS Classifications in Financial Research. Account. Finance 59, 1131-1162. doi:10.1111/acfi.12285

Le, D. V., Le, H. T. T., and Vo, L. V. (2021). The Bright Side of Product Market Threats: The Case of Innovation. Int. Rev. Econ. Finance 71, 161-176. doi:10.1016/j.iref.2020.09.008

Lee, C. M. C., Ma, P., and Wang, C. C. Y. (2015). Search-based Peer Firms: Aggregating Investor Perceptions through Internet Co-searches. J. Financial Econ. 116, 410-431. doi:10.1016/j.jfineco.2015.02.003

Li, D., Zheng, M., Cao, C., Chen, X., Ren, S., and Huang, M. (2017). The Impact of Legitimacy Pressure and Corporate Profitability on green Innovation: Evidence from China Top 100. J. Clean. Prod. 141, 41-49. doi:10.1016/j.jclepro.2016.08.123

Liao, Z. (2018). Environmental Policy Instruments, Environmental Innovation and the Reputation of Enterprises. J. Clean. Prod. 171, 1111-1117. doi:10.1016/ j.jclepro.2017.10.126

Lin, H., Zeng, S. X., Ma, H. Y., Qi, G. Y., and Tam, V. W. Y. (2014). Can Political Capital Drive Corporate green Innovation? Lessons from China. J. Clean. Prod. 64, 63-72. doi:10.1016/j.jclepro.2013.07.046

Lv, X., Qi, Y., and Dong, W. (2020). Dynamics of Environmental Policy and Firm Innovation: Asymmetric Effects in Canada's Oil and Gas Industries. Sci. Total Environ. 712, 136371. doi:10.1016/j.scitotenv.2019.136371

Lyandres, E., and Palazzo, B. (2016). Cash Holdings, Competition, and Innovation. J. Financ. Quant. Anal. 51, 1823-1861. doi:10.1017/ S0022109016000697

Marshall, G., and Parra, Á. (2019). Innovation and Competition: The Role of the Product Market. Int. J. Ind. Organ. 65, 221-247. doi:10.1016/ j.ijindorg.2019.04.001

Mulkay, B. (2019). How Does Competition Affect Innovation Behaviour in French Firms? Struct. Change Econ. Dyn. 51, 237-251. doi:10.1016/ j.strueco.2019.05.003

Murphy, L., Huggins, R., and Thompson, P. (2016). Social Capital and Innovation: A Comparative Analysis of Regional Policies. Environ. Plann. C Gov Pol. 34, 1025-1057. doi:10.1177/0263774X15597448

Newell, R. G. (2010). The Role of Markets and Policies in Delivering Innovation for Climate Change Mitigation. Oxford Rev. Econ. Pol. 26, 253-269. doi:10.1093/ oxrep/grq009

Noci, G., and Verganti, R. (1999). Managing 'green' Product Innovation in Small Firms. ReD Manag. 29, 3-15. doi:10.1111/1467-9310.00112

Oduro, S., Maccario, G., and De Nisco, A. (2021). Green Innovation: a Multidomain Systematic Review. Ejim ahead-of-print, 1. doi:10.1108/EJIM10-2020-0425

Park, B.-J., Srivastava, M. K., and Gnyawali, D. R. (2014). Walking the Tight Rope of Coopetition: Impact of Competition and Cooperation Intensities and Balance on Firm Innovation Performance. Ind. Marketing Manag. 43, 210-221. doi:10.1016/j.indmarman.2013.11.003

Peneder, M., and Woerter, M. (2014). Competition, R\&D and Innovation: Testing the Inverted-U in a Simultaneous System. J. Evol. Econ. 24, 653-687. doi:10.1007/s00191-013-0310-z

Schumpeter, J., and Backhaus, U. (2021). “The Theory of Economic Development," in Joseph Alois Schumpeter (Boston: Kluwer Academic Publishers), 61-116. doi:10.1007/0-306-48082-4_3

Stucki, T., Woerter, M., Arvanitis, S., Peneder, M., and Rammer, C. (2018). How Different Policy Instruments Affect green Product Innovation: A Differentiated Perspective. Energy Policy 114, 245-261. doi:10.1016/j.enpol.2017.11.049

Tang, J. (2006). Competition and Innovation Behaviour. Res. Pol. 35, 68-82. doi:10.1016/j.respol.2005.08.004

Tariq, A., Badir, Y. F., Safdar, U., Tariq, W., and Badar, K. (2019). Linking Firms' Life Cycle, Capabilities, and green Innovation. Jmtm 31, 284-305. doi:10.1108/ JMTM-08-2018-0257

Thomas, A., Scandurra, G., and Carfora, A. (2021). Adoption of green Innovations by SMEs: an Investigation about the Influence of Stakeholders. Ejim ahead-ofprint, 1. doi:10.1108/EJIM-07-2020-0292

Uyarra, E., Zabala-Iturriagagoitia, J. M., Flanagan, K., and Magro, E. (2020). Public Procurement, Innovation and Industrial Policy: Rationales, Roles, Capabilities and Implementation. Res. Pol. 49, 103844. doi:10.1016/j.respol.2019.103844

Wang, N., and Hagedoorn, J. (2014). The Lag Structure of the Relationship between Patenting and Internal R\&D Revisited. Res. Pol. 43, 1275-1285. doi:10.1016/ j.respol.2014.03.010 
Wang, N., and Mogi, G. (2017). Deregulation, Market Competition, and Innovation of Utilities: Evidence from Japanese Electric Sector. Energy Policy 111, 403-413. doi:10.1016/j.enpol.2017.09.044

Wang, X., and Zou, H. (2018). Study on the Effect of Wind Power Industry Policy Types on the Innovation Performance of Different Ownership Enterprises: Evidence from China. Energy Policy 122, 241-252. doi:10.1016/j.enpol.2018.07.050

Weiss, C. R., and Wittkopp, A. (2005). Retailer Concentration and Product Innovation in Food Manufacturing. Eur. Rev. Agric. Econ. 32, 219-244. doi:10.1093/eurrag/jbi022

Xia, T., and Liu, X. (2017). Foreign Competition, Domestic Competition and Innovation in Chinese Private High-Tech New Ventures. J. Int. Bus Stud. 48, 716-739. doi:10.1057/s41267-017-0083-y

Xiang, C., Chen, F., Jones, P., and Xia, S. (2021). The Effect of Institutional Investors' Distraction on Firms' Corporate Social Responsibility Engagement: Evidence from China. Rev. Manag. Sci. 15, 1645-1681. doi:10.1007/s11846-02000387-z

Yi, M., Fang, X., Wen, L., Guang, F., and Zhang, Y. (2019). The Heterogeneous Effects of Different Environmental Policy Instruments on green Technology Innovation. Ijerph 16, 4660. doi:10.3390/ijerph16234660

Yuan, B., and Zhang, Y. (2020). Flexible Environmental Policy, Technological Innovation and Sustainable Development of China's Industry: The Moderating Effect of Environment Regulatory Enforcement. J. Clean. Prod. 243, 118543. doi:10.1016/j.jclepro.2019.118543

Zhang, L., Chen, F.-W., Xia, S.-M., Cao, D.-M., Ye, Z., Shen, C.-R., et al. (2021). Value Cocreation and Appropriation of Platform-Based Alliances in Cooperative Advertising. Ind. Marketing Manag. 96, 213-225. doi:10.1016/j.indmarman.2021.06.001
Zhang, Y., Sun, J., Yang, Z., and Wang, Y. (2020). Critical success Factors of green Innovation: Technology, Organization and Environment Readiness. J. Clean. Prod. 264, 121701. doi:10.1016/j.jclepro.2020.121701

Zhang, Y., Zhang, J., and Cheng, Z. (2021). Stock Market Liberalization and Corporate green Innovation: Evidence from China. Ijerph 18, 3412. doi:10.3390/ijerph18073412

Zhao, Y., Feng, T., and Shi, H. (2018). External Involvement and green Product Innovation: The Moderating Role of Environmental Uncertainty. Bus Strat Env 27, 1167-1180. doi:10.1002/bse.2060

Conflict of Interest: The authors declare that the research was conducted in the absence of any commercial or financial relationships that could be construed as a potential conflict of interest.

Publisher's Note: All claims expressed in this article are solely those of the authors and do not necessarily represent those of their affiliated organizations, or those of the publisher, the editors and the reviewers. Any product that may be evaluated in this article, or claim that may be made by its manufacturer, is not guaranteed or endorsed by the publisher.

Copyright (C) 2022 Huang and Chen. This is an open-access article distributed under the terms of the Creative Commons Attribution License (CC BY). The use, distribution or reproduction in other forums is permitted, provided the original author(s) and the copyright owner(s) are credited and that the original publication in this journal is cited, in accordance with accepted academic practice. No use, distribution or reproduction is permitted which does not comply with these terms. 